\title{
ABNORMAL DEVELOPMENT OF TOAD OVA FER- TILIZED BY SPERMATOZOA EXPOSED TO THE ROENTGEN RAYS
}

\author{
B $\mathbf{Y}$ \\ CHARLES RUSSELL BARDEEN, M.D. \\ Professor of Anatomy, University of Wisconsin, Madison, $W$ is. \\ With Five Plates \\ REVIEW OF THE LITERATURE
}

The marked alterations in structure and function produced in living tissues by the Roentgen rays and the rays of radium have excited much interest in the medical profession. Professional biologists have paid less attention to the subject, although it is one which promises to be of great importance to those engaged in experimental morphology. While probably all living tissues may be injured by sufficient exposure to these rays, there are great differences in the degree of susceptibility of different tissues and organisms. The power of assimilation of foodstuffs and their transformation into living structures complex in character seems to be that which is most altered in exposed tissues.

Bacteria are less easily affected than are most of the higher organisms. Many of those who have exposed cultures of bacteria to the Roentgen rays have failed to discover any checking of the normal multiplication of the bacteria. ${ }^{1}$ Rieder, ${ }^{2}$ on the other hand, found growth of bacteria inhibited by sufficient exposure to the rays. Those who have studied the action of radium on bacterial cultures have usually found the growth of the bacteria inhibited

${ }^{1}$ Park, Medical News, 1896; Mink, Münchener med. Wochenschrift, 1896; Lyon, Lancet, 1896; Delepine, British Medical Journal, 1896; Atkinson, Nature, lvi, p. 600, 1897 (negative results with mucor, bacteria and oscillaria).

2Rieder: Münchener med. Wochenschrift, I902.

The Journal or Experimental Zoölogy, vol. iv, no. I. 
by its rays. ${ }^{3}$ Koernicke ${ }^{4}$ found the development of yeast and bacteria inhibited by exposure to the rays but that the exposed cultures, if transferred to fresh unexposed gelatine, could begin to grow again.

The action of the Roentgen rays and radium on the higher plants has been recently studied by M. Koernicke, ${ }^{5}$ who gives references to the previous literature on the subject. Koernicke finds that the Roentgen rays serve to check the growth of germinating seeds. Immediately after exposure there may be a slight quickening of growth. The retardation of development appears only after a latent period. If the exposure to the rays is not too intense or prolonged, the retardation of growth is merely transitory; if sufficiently intense, there is permanent inhibition of growth. Exposure of dry seeds and swollen, non-germinating seeds to the Roentgen rays had no immediate inhibitive effect on subsequent germination. Instead a slight quickening of germination was sometimes seen. Ultimately, however, the roots of the exposed seeds ceased to grow. According to Maldiney and Thouvenin ${ }^{6}$ exposure to the Roentgen rays hastens germination of seeds. Lopriore ${ }^{7}$ found the germination of pollen inhibited by the rays.

A pupil of H. Becquerel ${ }^{8}$ found that while 24 hours' exposure of certain seeds to radium rays caused no marked diminution in power of germination, an exposure of a week or more inhibited the process. Koernicke did not inhibit growth in the seeds he studied (Vicia faba, Brassica napus, Papaver somniferum), but he found that exposure to radium rays caused a subsequent checking or inhibition of growth in germinating seeds and that nongerminating seeds either dry or moist, if sufficiently exposed,

${ }^{3}$ Aschkinass and Caspari: Arch. für die Ges. Physiol., luxxvi, 1901 (action attributed to $a$ and $\beta$ rays). W. Hoffmann: Hyg. Rundsch, xiii, s. $9^{1} 3$, 1903 (bacteria killed). Dixon and Wigham: Nature, Ixix, pp. 81, 1903 (bacteria checked in growth). Danysz: Compt. Rend., cxxxii, p. 463, 1903. H.v: Baeyer; Zeitschrift f. allgem. Physiologie, iv, p. 79, 1904.

${ }^{4} \mathrm{M}$. Koernicke: Berichte der Deutsche Bot. Gesellschaft, xxii, s. $16_{3}, 1904$.

${ }^{5} \mathrm{M}$. Koernicke: Ueber die Wirkung von Röntgen- und Radiumstrablen auf den pflanzlichen Organismus. Berichte der Deutschen botanische Gesellschaft, xxii, pp. 148-166, 1904; xxiii, pp. 404414, 1905 .

${ }^{6}$ Maldiney and Thouvenin: Reque gen. de Bot., x, p. 81, 1898 .

${ }^{7}$ Lopriore: Estr. dal' Nuova Rassegna, Catania, 1897 .

${ }^{8}$ H. Becquerel: Comptes Rendus, $t$. 133 , pp. 712, 19or. 
germinate normally at first and then show a temporary or permanent inhibition of growth. Koernicke found in studying the tissues of exposed plants that it is the nuclei that seem especially affected by the rays. There is no visible direct injury to the cytoplasm. The effect on the nuclei is proportional to the length of exposure. The nuclei of the vegetative cells are more resistant than the pollen mother-cells. Owing to injury to the nuclei of the pollen mother-cells the pollen cells may be abnormal in appearance but this is due to the action of the injured nuclei on the cytoplasm.

In the pollen mother-cells twenty-four hours after five hours' exposure to radium rays the nuclear threads'during mitosis fell into small double segments which were much smaller and more numerous than normal for Lilium martagon (the species studied). Division of the chromosomes took place somewhat in the normal manner but the daughter chromosomes seldom passed simultaneously toward the poles. Occasionally two or three daughter nuclei were formed on each side of the equator. If the pollen mother-cells shortly before the diakinesis of the nuclei were exposed for twenty-four hours, they showed a day later a clumping of the chromosomes at the center of the nuclear cavity. The spindle figure was strongly developed. Sometimes the spindle poles seemed split.

Exposure to radium rays up to ten hours seemed to have little effect on the daughter cells of the pollen mother-cells, but a one to three days' exposure had a marked effect. The nuclei were brought into an abnormal stage which partially resembled a resting stage. The nuclei of the tetrads arising from exposed cells were also very abnormal.

The effects of the Roentgen and radium rays on a protozoa have been studied by Schaudinn, Joseph and Prowazek, Zuelzer, and others. Schaudinn ${ }^{9}$ showed that individuals of several species of protozoa may be killed by exposure to the Roentgen rays for a few hours, while others are not thus susceptible. Joseph and Prowazek ${ }^{10}$ found that Paramecia and Daphnia show a negative

'Schaudinn: Archiv. f. die gesammte Physiologie, Ixrvii, p. 29, I899.

${ }^{10} \mathrm{Joseph}$ and Prowazek: Zeitschr. für allg. Physiol., Bd. i, Igoz. 
tropism toward the Roentgen rays, and that the protoplasm of Paramecia seems injured by the rays. I have found paramecia very resistant to the Roentgen rays. Twelve hours' exposure to powerful rays made no difference in the form or rate of division in P. aurelia or P. candatum. Exposure to the rays seemed not to influence conjugation. M. Zuelzer in protozoa which were exposed to radium rays under the microscope noted primarily an injury to the nuclear substance. The cytoplasm appeared affected later than the nuclei. Great variation in susceptibility was noted in different species. Zuelzer gives a brief summary of the previous literature on this subject.

Zuelzer ${ }^{11}$ found insects, and Danysz ${ }^{12}$ insect larvæ affected by radium rays.

The action of Roetgen and radium rays on the fertilized eggs of Ascaris megalocephala has been studied by Perthes. ${ }^{13}$ Perthes found that there is a retardation of the cleavage of eggs exposed to the rays and that the later divisions are either inhibited or are abnormal. In the latter case the eggs give rise to either irregular masses of cells or to abnormal embryos. The effects depend largely on the degree of exposure. The nuclei of the exposed eggs are markedly affected. The chromosomes of the dividing nuclei are irregular in shape and sometimes seem to be divided abnormally into smaller parts. The spindle figures appear normal.

In fresh water Planarians Bardeen and Baetjer ${ }^{14}$ showed that exposure to the Roentgen rays destroys the power of regeneration. Schape ${ }^{15}$ has shown that exposure to radium rays produces similar effects.

The action of Roentgen rays on the developing eggs of seaurchins was found to be negative by G. Schwarz. ${ }^{10}$ In the spring of 1903 the writer failed to get any positive results on exposing the eggs of sea-urchins and teleosts to the Roentgen rays, but these

${ }^{11}$ M. Zuelzer: Archiv für Protistenkunde, v, p. 358, 1905.

${ }^{12}$ Danysz: Compt. Rend., crxxvi, 1903.

${ }^{18}$ Perthes: Archiv für klinische Chirurgie, 1xxi, 1903; Deutsche med. Wochenschrift, Nr. $17-18,1904$.

${ }^{14}$ Bardeen and Baetjer: This journal, i, p. 192, 1904.

${ }^{15}$ Schaper: Anat. Anzeiger, $\mathbf{x x v}$ p. 298, 1904.

${ }^{16}$ G. Schwarz: Wiener klin. Wochenschrift, xvi, s, 714, 1903 . 
negative results he attibuted to the use of an apparatus from which rays of merely moderate intensity could be obtained and which could not be used for prolonged exposures. G. Bohn ${ }^{17}$ has reported the production of arificial parthenogenesis in Strongylocentrotus lividus by exposure to the rays of radium.

The effects of the exposure of the fertilized eggs and the larvæ of Amphibia to the Roentgen and radium rays have been studied by a number of investigators. P. K. Gilman and F. H. Baetjer ${ }^{18}$ have shown that the eggs of Amblystoma exposed to the Roentgen rays exhibit a brief period of accelerated growth and then markedly abnormal development. If the exposure is not too severe the tadpoles may recover; if sufficiently severe they develop into monstrosities and soon die. A. Schaper" obtained somewhat similar results with frogs' eggs exposed to radium rays, although he failed to find a period of accelerated growth immediately following exposure. Schaper also found that regeneration of the tail and limbs of 'Triton larvæ is inhibited by exposure to radium rays. The wound heals and a mass of cells is accumulated in the region of the lost part but no specific regeneration takes place. O. Levy, ${ }^{20}$ who has studied microscopically the specimens prepared by Schaper just before his untimely death, comes to the following conclusions :

I In the period of cleavage of the ovum the rays may serve to check or inhibit cell division but cause no cell degeneration. Death may follow.

2 In the period of formation and early differentiation of the organs (generative self-assimilation) marked degenerative abnormalities appear in many of the organs, especially in the neural tube, retina and nose. The optic lens, the pigment layer of the retina, the aural vesicle, the chorda dorsalis, and the myotomes appear comparatively little affected. The heart is frequently rudimentary. The tubules of the pronephros are frequently dilated. In general, the effects are the most serious in those tissues in which growth and complex differentiation are normally most rapid.

\footnotetext{
${ }^{17}$ G. Bohn: Comptes Rendus de l'Acad. des Sciences, Paris, cxxxvi, pp. 1012, 1085, 1903.

${ }^{18}$ P. K. Gilman and F. H. Baetjer: Amer. Jour. of Physiology, x, p. 222; I904.

${ }^{10}$ A. Schaper: Anat. Anzeiger, xxv, p. 298, I904; Deutsche med. Wochenschrift, xxx, 1904.

${ }^{20} \mathrm{O}$. Levy: Archiv f. Entwicklungsmechanik, xxi, p. 130-152, 1906.
} 
3 In the period of the finer differentiation of the organs (functional development of Roux) the primary effect of exposure appears to be on the blood vessels, the tissues suffering because of the effects on the blood vessels.

G. Bohn, ${ }^{21}$ who studied the effects of radium rays on the eggs and larva of the frog and turtle, found that if growth is slow exposure to radium rays prevents the attainment of full size; if rapid and associated with tissue differentiation, radium causes degeneration of the tissues and although at first accelerating, ultimately stops development. He considers that everything leads one to think that the rays of radium affect the chromatine because it is from the activity of this substance that there results assimilation and growth.

The action of the Roentgen rays on the hen's egg has been studied by Gilman and Baetjer. ${ }^{22}$ These investigators found a preliminary period of accelerated development followed by retardation of development and the production of abnormal embryos. $\mathrm{J}$. Tur ${ }^{23}$ studied the action of radium rays on developing hen's eggs and obtained various deformities. He found the embryonic area of the germinal disc more sensitive to the rays than the periphery and obtained some germinal discs without embryos. He found the cells of the ectoderm more easily affected than the yolk cells. G. Schwarz, ${ }^{24}$ on the other hand, from his experiments on the action of radium rays on the hen's egg, concludes that the action of the rays is due to a decomposition similar to that of a dry distillation brought about in the albumenoid bodies of the cell. He explains the effect of the rays on rapidly growing tissue as due to their special power to decompose lecithin. Perthes ${ }^{25}$ found that the wing of a chick exposed to radium rays was checked in its development.

The experiments with radium and Roentgen rays on plants, invertebrates and the lower vertebrates, though of great scientific

${ }^{21} \mathrm{G}_{\text {}}$ Bohn: Op. cit.

${ }^{22}$ Gilman and Baetjer: Op, cit.

${ }^{23}$ J. Tur: Comptes Rendus des Séances de la Société de Biologie, t. Ivii, 1904 .

${ }^{24} \mathrm{G}$. Schwarz: Archiv f. gesammte Physiologie, C. 532, 1903.

${ }^{25}$ Perthes: Archiv f. klin. Chirurgie, 1xxi, 1903. 
value, have been comparatively few in number. The practical application of the rays in medicine has led to a much more extensive series of observations on the effects of the rays on man and mammals.

The physiological effect of the Roentgen rays first noticed was the skin burn which after an interveniug latent period usually follows much exposure to the rays, and which may give rise to great thickening of the skin or to ulceration. Similar lesions were found to follow exposure to the salts of radium and like substances. Clincal experience as well as experiments on various mammals soon showed that the more deeply seated tissues, as well as the skin, are affected by the rays, but that the different tissues are variously affected. SSome tissues seem to be affected directly, others seem to be affected only indirectly through alternations produced in the general metabolism or in the blood supply.

General toxic effects following the exposure to the Roentgen rays have been described in man by Seguy and Quenisset, ${ }^{28} \mathrm{Walsh},{ }^{27}$ Kienbock, ${ }^{28}$ Baermann and Linser, ${ }^{28}$ A. S. Warthin,${ }^{30} \mathrm{D}$. Edsall, ${ }^{31}$ and many others. ${ }^{32}$ Similar effects have been described in many mammals. Tarkhanoffss experimented not only with several small mammals (mice, rabbits and guinea pigs) but also upon frogs and birds. He found that when long exposed the animals died with symptoms of paralysis. Rodet and Bertin ${ }^{34}$ attributed the death of animals exposed to $\mathrm{X}$-rays to a meningo-myelitis. Numerous subsequent experimenters have described toxic effects, paralytic symptoms and death in small mammals after prolonged exposure to the Roentgen and radium rays. Danysz ${ }^{35}$ was one of the first to study this action of radium on small mammals. He found that a pro-

\footnotetext{
${ }^{20}$ Seguy and Quenisset: Bulletin de l'Acad, des Sciences, 1897 .

${ }^{27}$ Walsh: British Med. Journal, 1897 .

${ }^{28}$ Kienbock: Wiener med. Presse, 19or.

${ }^{20}$ Baermann and Linser: Münchener med. Wochenschrift, 1i, s. 918-994, 1904.

${ }^{30} \mathrm{~A}$. S. Warthin, International Clinics, 15 th series, vol. iv, p. 243, 1906.

${ }^{31}$ D. Edsall, Journal American Medical Association, xlvii, p. 1425, 1906.

${ }^{32}$ For a list of the literature on this subject, see Warthin, op. cit.

${ }^{39}$ Tarkhanoff: Gaz. degli ospedali, 1897 . (Cited by Warthin.)

${ }^{34}$ Rodet and Bertin: Gaz. des Hôp., 1898. (Cited by Warthin.)

${ }^{35}$ Danysz: Comptes Rendus de l'Acad. des Sciences, Paris, 1903, 1904.
} 
longed application of the tube containing the radium salt to the head or spine of a small mammal was followed by paralysis, ataxia, convulsions and death. In the central nervous system marked hemorrhagic lesions were found after death. Similar alterations in the central nervous system have been described by Heineke, ${ }^{\mathbf{3 6}}$ Scholtz, ${ }^{37}$ Obersteiner, ${ }^{38}$ and others. Obersteiner, who paid especial attention to the lesions of the central nervous system, concludes that "the various phenomena which are observed in the exposed mice, including the death which follows sufficient exposure to the rays, in greatest part are, directly or indirectly, merely an expression of a general disturbance of the circulation and of metabolism produced by the radium rays." Obersteiner does not consider the nerve cells specifically susceptible to the rays although they are, more easily than many tissues, disturbed by alteration in the circulation or general metabolism. The general disturbances produced by the rays are indicated by the increased elimination of nitrogen discovered to take place by Baermann and Linser ${ }^{39}$ after severe exposure. Lepine and Bonlud ${ }^{40}$ had previously shown that alterations affecting metabolism take place in the pancreas, liver and blood after exposure to the Roentgen rays. The great susceptibility of the nervous system to the indirect, if not to the direct, action of the rays, is shown not only by the lowering of the reflexes, a pathy and paralysis which precede death in animals sufficiently exposed to the Roentgen or the radium rays, but also by the injury of the retina and secondary atrophy of the optic nerve which Birch-Hirschfeld ${ }^{41}$ has described. Trophic disturbances may likewise possibly be due to the injured nervous system. Obersteiner ${ }^{42}$ has described a severe panophthalmitis and a gangrene of the tendons of the feet, the ears and the nose following exposure of mice to radium.

While there is doubt concerning the specific sensibility of the

\footnotetext{
${ }^{30}$ Heineke: Münchener med. Wochenschrift, 1, s. 2090, 1903.

${ }^{37}$ Scholtz: Deutsche med. Wochenschrift, xxx, 8. 94, 1904.

${ }^{38}$ Obersteiner: Arbeiten aus dem Neurologischen Institute, Wien, rii, p. 86, 1905.

${ }^{39}$ Baermann and Linser: Op. cit,

${ }^{40}$ Lepine and Bonlud: Comptes Rendus de l'Acad. des Sciences, Paris, t. xxxriii, 1904.

${ }^{11}$ Birch-Hirschfeld: Münchener med. Wochenschrift, 1904 .

${ }^{42}$ Obersteiner: Op. cit.
} 
nervous system to radium, most investigators are agreed concerning the marked action which radium and Roentgen rays have on the vascular system. Although the action of the rays on plants and ova shows conclusively that other than the vascular tissues may be directly affected by the rays, the changes in the blood vessels in young or a dult ma mma lian tissues are a mong the most marked lesions found after exposure to the rays, so that the effect on other organs, a swell as on the central nervous system, has been described by many as due to a secondary action on the tissues through a primary injury of the vascular system. While even the well-known lesions of the skin have been ascribed to action on the blood vessels or nerves, Oudin, Barthélmy and Darier ${ }^{13}$ found in a study of Roentgen ray alopecia in guinea pigs that the layers of the epidermis were affected, the follicles and glands were atrophied but no alterations in the blood vessels and nerves of the dermis or subcutaneous were to be observed. Scholtz, ${ }^{44}$ in an important contribution, concluded that both the nuclei and the cell protoplasm of the epithelial cells of the mammalian skin are injured by the rays, but that the effect on the connective tissues, elastic tissues, musculature and cartilage is slight. The skin on both sides of a rabbit's ear may be affected when it is exposed to rayson one side only. The effect on the connective tissues he thinks due to a secondary inflammatory reaction. Gassmann, ${ }^{45}$ from a study of a deep Roentgen ray ulcer, concluded that the changes in the blood vessels formed the primary cause of the ulcer and its resistance to healing. RudisJicinsky, ${ }^{\text {to }}$ from an experimental study of $X$-ray burns in guinea pigs and rabbits, concluded that there is an inflammatory reaction to the X-rays followed by a development of fibrous tissue and a thickening of the walls of the blood vessels, and that degenerative changes follow the impaired blood supply. Baermann and Linser, ${ }^{47}$ from a study of the action of X-rays on lupus, concluded that an endarteritis and contraction of the blood vessels with degenerative

\footnotetext{
${ }^{43}$ Oudin, Barthélmy and Darier: Monatsch. f. prakt. Dermat., xIv, 1897.

${ }^{44}$ Scholtz: A rchiv f. Dermatologie u. Syphilis, lix, pp. 87, 241, 419, 1902.

${ }^{45}$ Gassmann: Fortschr. a. d. Geb. d. Roentgenbestr., I899.

${ }^{46}$ Rudis-Jicinsky: New York Med. Jour., Igo2.

${ }^{47}$ Baermann and Linser: Münchener med. Wochenschrift, 1904.
} 
changes in the connective tissue is the primary result of the action of the rays, the epithelium being only secondarily affected. While there is little doubt but that the deepest layer of the epidermis is affected primarily by the Roentgen and radium rays, as shown by Scholtz, ${ }^{48}$ the recent work of Scholtz, ${ }^{40}$ Halkin, ${ }^{50}$ and others, has proved that exposure to radium rays, at least, also has a primary effect on the intima of the blood vessels. Whether the effect on the collagen of the connective tissues described by Unna, ${ }^{51}$ and others, is secondary to the vascular changes or is a primary effect of the rays cannot at present be conclusively answered.

Exposure to Roentgen or radium rays has a marked effect not only on the blood vessels but also upon the blood and especially upon the blood-forming organs. Baermann and Linser ${ }^{52}$ found no changes in the blood exposed to Roentgen rays. The irradiation of serum caused, however, a decrease of hæmolytic power toward blood corpuscles not exposed. Milchner and Mosse ${ }^{53}$ found red blood corpuscles resistant to the Roentgen rays. London ${ }^{54}$ noted

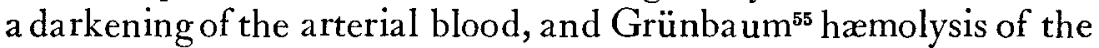
red corpuscles after exposure to the radium rays.

In the spleen, lymphatic glands and bone marrow the results of irradiation are more marked than in the blood. Milchner and Mosse $^{56}$ found in the bone marrow of irradiated rabbits degeneration of lymphoid and myeloid leucocytes but no destruction of the red corpuscles. Heinecke ${ }^{57}$ exposed rabbits, white mice, guinea pigs and dogs to the Roentgen and radium rays and found an elective action on the lymphoid elements of the spleen, lymphatic glands and bone marrow. These organs ultimately become much reduced in cell content. Warthin ${ }^{58}$ began independently and

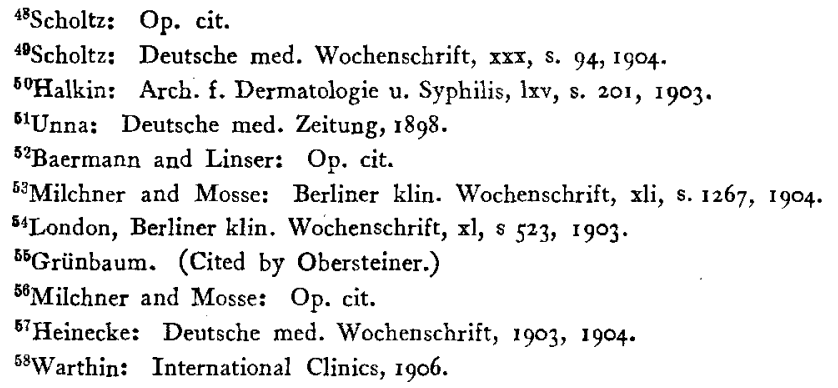


carried farther than Heinecke an experimental study of the action of the Roentgen rays on the blood-forming organs. Warthin's paper contains an extensive list of references to the literature relating to this subject, of which use has been made in preparing the present paper. Warthin employed white rats, rabbits, Belgian hares, and guinea pigs in his experiments and subjected them to brief and to prolonged exposures. Exposures of five hours or more caused death, usually in from two to five days. In all animals exposed destructive changes were found in the lymphoid elements of the splenic pulp and follicles, marked by a degeneration of phagocytes, giant cells, and the epitheloid cells of the follicles. In all animals the effects lasted for some time and were not immediately followed by regeneration. A hæmolytic action was indicated by the great increase of blood pigment in the tissues. Warthin suggests, however, that this may have been due in part to disturbances of splenic function. A fatty degeneration was noted in the lymphoid tissues. The disintegration of lymphocytes was seen within 14 minutes after exposure and the cells continued to disintegrate for several days. The greater part of the nuclear débris was quickly removed. The Roentgen rays caused also a destruction of the lymphoid cells of the lymphatic glands. The small lymphocytes were destroyed before the other cells. Slight irradiation caused fatty degeneration; intense irradiation, nuclear degeneration. Regeneration sometimes took place after irradiation was discontinued. The effects in the bone marrow were less intense than those in the spleen and lymphatic glands. The large lymphocytes and myelocytes were chiefly attacked ${ }_{\boldsymbol{\gamma}}$ the small lymphocytes not showing the marked disintegration found in the spleen. No effect on the red cells was discerned. There was an undoubted inhibition of white cell production in the marrow after irradiation.

Pusey, ${ }^{59}$ Senn, ${ }^{60}$ and a number of other American physicians, introduced the treatment of leucæmia by the use of the Roentgen rays. Pusey ${ }^{61}$ attributes to Dr. A. J. Ochsner the first suggestion

\footnotetext{
${ }^{50}$ Pusey: Jour. Amer. Med. Association, 1902.

${ }^{60}$ Senn: New York Med. Journal, 1903.

"Pusey: Jour. Amer. Med. Association, 1905.
} 
of this treatment. A large number of papers on the subject have been reported. A list may be found in the paper of Warthin, mentioned above. While nearly all of the leukemic cases treated have shown at first a marked improvement in the blood condition and general symptoms, there is some doubt as to the possibility of a permanent cure being brought about by irradiation with the Roentgen rays. Many of the earlier cases reported as cured have since relapsed or died. Warthin studied tissues derived from three patients who had been treated by X-ray irradiation for leukemia. In one there was a picture of an aleukemic lymphocytoma or lymphosarcoma with no lymphocytes in the vessels; in the second the tissues presented the picture of a myeloid leukemia without any changes attributable with certainty to the Roentgen ray treatment; in the third the immediate effect of the treatment was to cause in the diseased glands a fatty degeneration and necrosis of the atypical cells forming the glands. This necrosis was usually followed by an apparent sarcomatous infiltration of the surrounding tissues. In the first and third cases renal lesions suggested toxemia. The symptoms leading to death Warthin thinks are due to an intoxication resulting from the disintegration of cell proteid.

The Roentgen rays have proved of more certain value in a number of other affections, especially in acne, rosacea, nevi, lupus vulgaris, cutaneous carcinoma, and some other superficially placed diseased conditions. ${ }^{22}$ In some instances the benefit seems to be due to a slight inflammatory reaction set up by the rays; in others to the alterations produced in the tissues When the rays have direct access to the tissues, diseased cells, especially the abnormal cells which constitute carcinomata and sarcomata, may apparently be destroyed by Roentgen or radium rays before permanent injury is inflicted on the normal tissues. When filtered through normal tissues the rays seem largely to lose an elective action on the abnormal cells. ${ }^{\text {a }}$

\footnotetext{
${ }^{62}$ See Pusey, Jour. Amer. Med. Assoc., I905.

${ }^{63}$ For a list of references to the literature on the action of the Roentgen rays on tumors, see Warthin International Clinics, igo6. On the action of radium irradiation on tumors, see H. Rieder, Verhandlung der Gesellschaft deutschen Naturforscher und Aerzte, I903, p. 278; H. Apolant, Deutsche med. Wochenschrift, xxx, s. 554, 1126, 1904; and Neuberg, Zietschr.f. Krebsforschnung, ii, s. 171, I 904 .
} 
Normal or slightly diseased tissues may be rendered carcinomatous or sarcomatous. Carcinomata have resulted from the action of the Roentgen rays on the skin; and sarcomata have arisen apparently from the action of the X-rays on the lymphatic glands. ${ }^{64}$

It is well known that sterility can be brought about in man and other mammals by sufficient exposure of the testicles to the Roentgen or radium rays. Several operators have thus been rendered sterile. Of those who have studied the action of the rays on spermatogenesis mention may be made of Albers-Schönberg, ${ }^{65}$ Frieben, ${ }^{60}$ Scholtz, ${ }^{67}$ Sedlin ${ }^{88}$ and Philipp. ${ }^{69}$ The exposure to the rays causes destruction of the spermatogonia and brings about aspermia.

Exposure of the ovaries to the rays causes similar disturbances. According to Halberstaeder ${ }^{70}$ the ovaries are more susceptible to the rays than are the skin and testicles.

In reviewing the literature on the effects of the Roentgen and radium rays on living organisms it becomes evident that both forms of irradiation have essentially similar, if not identical, physiological action. The Roentgen rays lend themselves the more readily to exposures powerful in volume and intensity but limited in time, the radium rays are as a rule much less voluminous but can more readily be applied over considerable intervals of time. The difference in the phenomena observed after exposure to the two sources of radiant energy may perhaps be ascribed mainly to this, although it is probable that the less penetrating rays of radium modify the effects produced by the $r$-rays. The latter are supposed to be identical with the more penetrating of the Roentgen rays. Schaper ${ }^{71}$ found the frog larvæ exposed to radium emanations a pparently adversely affected, yet Levy ${ }^{22}$ was unable to find

\footnotetext{
${ }^{64}$ Warthin: Op. cit.

${ }^{65}$ Albers-Schonberg: Münchener med. Wochenschrift, 1903.

${ }^{68}$ Frieben: Münchener med. Wochenschrift, 1903.

${ }^{87}$ Scholtz: Deutsche med. Wochenschrift, 1904.

${ }^{68}$ Sedlin: Fortschr. a. d. Gebiete d. Roentgenbestr., vii, I904.

${ }^{60}$ Philipp: Fortschr. a. d. Gebiete d. Roentgenbestr., viii, 1905.

${ }^{70}$ Halberstaeder: Berliner klin. Wochenschrift, 1905.

${ }^{71}$ Schaper: Anat. Anzeiger, $x \times v$, p. $278,1904$.

${ }^{72}$ Levy: Archiv für Entwicklungsmechanik, xxi, p. 142, 1906.
} 
in the larvæ exposed to radium emanation and preserved by Schaper, any evidences of tissue degeneration such as follows direct irradiation.

The Roentgen rays and the rays emitted by radio-active substances are known to cause ionization of gases, to affect photographic plates, phosphorescent substances and glass. It seems evident that they also modify the chemical nature of living bodies. It is certain that in some instances, at least, as proved by Perthes ${ }^{73}$ Thies, ${ }^{74}$ Koernicke, ${ }^{75}$ and others, the cell nuclei are primarily affected by the rays. An injury to nuclei of cells sufficient to destroy the normal influence over metabolism would suffice to account for all phenomena which have been observed. The special destructive influence on cells undergoing rapid assimilation, multiplication and differentiation may be accounted for by the very important rôle played by the nuclei in these processes and an apparently greater susceptibility of the nuclei at such periods. The recent important and suggestive paper of F. R. Lillie ${ }^{78}$ on the elementary phenomena of embryonic development in Chætopterus, shows what an active part is performed by the nuclei of cells during the early stages of embryonic development in furnishing substances to the cytoplasm and in turn assimilating substances from the cytoplasm. While irradiation does not as a rule directly stop the phenomena of mitosis it evidently severely alters the productive activities of the nuclei of the cells and thus affects metabolism. Irradiation may also possibly directly affect the cytoplasm and intercellular substances.

Thies ${ }^{77}$ from a careful study of the action of radium rays on the different mammalian tissues and organs comes to the conclu-. sion that all tissues suffer, although the elastic tissues are relatively resistant. The adenoid tissues are the most susceptible. Other very susceptible tissues are the epidermis, the intima of the blood vessels, the parenchyma of the sex glands, voluntary muscle, white

\footnotetext{
${ }^{73}$ Perthes: Archiv f. klin. Chirurgie, 1xxi, 1903; Deutsche med. Wochenschrift, 1904.

${ }^{74}$ Thies: Wirkung der Radiumstrahlen auf verschiedene Gewebe und Organe. Mitteil. aus den Grenzgebreden d. Medizin und Chirurgie, xiv, 1905.

${ }^{75}$ Koernicke: Berichte der deut. bot. Gesellschaft, 1904-05.

${ }^{76}$ Lillie: Jour. of Experimental Zoölogy, iii, pp. I54-263, 1906.

"Thies: Op. cit.
} 
fibrous tissues and cartilage. Neither Scholtz ${ }^{78}$ nor Danysz ${ }^{79}$ place the connective tissues or voluntary muscle among the tissues especially susceptible to irradiation.

The physiological chemical effects of irradiation are not yet clear. While some authors attribute much to the decomposition of lecithin, others deny that irradiation can decompose this substance. There is some evidence that the action of ferments is influenced by irradiation. ${ }^{80}$

\section{EXPERIMENTS}

The following experiments were designed primarily to test whether nuclear alteration produced by exposure to the Roentgen rays would alone suffice to cause the tissue alterations characteristic of this exposure. For this purpose I exposed spermatozoa to the $X$-rays and then fertilized eggs with these spermatozoa. Since the chief portion of the spermatozoön is the nucleus and since the mass of spermatozoön is insignificant compared to that of the egg it seems fair to conclude that if the exposure of the spermatozoön to the rays influences the development of the ovum the action of the rays must be on those unknown substances in the nucleus, or the protoplasm most intimately associated with the nucleus, which control the morphogenetic activities of the cell.

The toad was selected because it is comparatively easy to get both males and females at the height of sexual maturity and the spermatozoa will live for several hours in water after removal from the body. My procedure was to collect several pairs of toads, separate the males from the females and wash the latter for some time in running water. From the testicles and Wolfian ducts of two of the males a thick suspension of spermatozoa was obtained. This was slightly diluted and divided into two portions, one of

\footnotetext{
${ }^{7 y}$ Scholtz: Archiv f. Dermatologie u. Syphilis, is, 1yuz; Deutsche med. Wochenschrift, xxx, 1904.

${ }^{79}$ Danysz: Comptes Rendus de l'Acad. des Sciences, Paris, I903, 1904.

${ }^{80}$ Schwarz: Archiv f. die gesammte Physiologie, c. s. 532, 1903; Baermann and Linser: Münchener med. Wochensch., li, 1904; Danysz J.: Comptes Rendus de l'Acad. des Sciences, Paris, 1903, 1904; Henri and Mayer: Comptes Rendus, I904; Lepine and Bonlud: Comptes Rendus, 1904; Neuberg: Zeitschr. f. Krebsforschung, ii, s. 171, 1904; Harry: Journal of Physiol., xxix, 1904; E. Benjamin and A. V. Reuss: Münch. med. Wochenschr., liii, 1906.
} 
which was kept for control, the other was exposed for from one-half to two hours to powerful X-rays from a fairly hard tube. At the end of the exposure I opened several females to obtain if possible eggs immediately ready for laying. Several short pieces of strings of eggs were placed in the control dish and others in the dish which had been exposed to the rays. After fifteen to twenty minutes these strings were removed and placed in large dishes of water. The development of the control and the experiment ova was then watched from day to day until it seemed likely that the ova fertilized by the exposed sperm could no longer survive. Specimens of the control and experiment embryos were then preserved for microscopic study.

Several of the experiments proved of negative value because not even the spermatozoa of the control dish proved capable of fertilizing the eggs, owing either to too great a lapse of time between the removal of the sperm from the males or to a lack of sufficiently ripe ova. The season was so short that only a few successful experiments could be carried out but these were convincingly positive. All eggs fertilized by the control spermatozoa developed normally. One of these was finally attacked by some parasitic organisms, but even in this the tissues and organs showed microscopically perfectly normal relations. All eggs fertilized by the exposed spermatozoa, over fifty in number, developed abnormally, with a single exception. This ovum developed into an apparently normal tadpole but this tadpole died before any of its fellow control tadpoles. It died at a time when it could not be immediately preserved for microscopic examination.

\section{Outline of Experiments}

I, May 4. Owing, probably, to too great dilution of sperm and too great a length of time between removal from the body and the attempt at fertilization of the ova, neither the irradiated or the exposed sperm fertilized any ova.

II, May 5. Sperm exposed for two hours to X-rays about four inches from the tube. A large number of the spermatozoa were active at the end of this period After fertilization the control and 
experiment ova were divided into two lots, one of which was kept in lake water and one in the harder city water.

May 6. Between 50 and 75 per cent of the eggs in each of the four lots were in the blastula stage.

May 7. All fertilized eggs were in the gastrula stage.

May 8. All fertilized eggs were advanced to the stage in which the yolk plug appears small.

May 9-22. The eggs in the city water during this period developed much more slowly than the lake water eggs. The control eggs in the city water were apparently nearly all fertilized and developed apparently normally though slowly up to May I2 when, owing to the cover being left off the shallow dish in which they were contained, and consequent evaporation of water during the absence of the writer from the city, the whole lot was destroyed. Of the experiment ova kept in city water about $5^{\circ}$ per cent developed. On May I I seventeen unfertilized and partially developed eggs were removed, leaving eleven nearly normal larvæ with very short caudal processes. On May I3 only six of these were still alive. These six were then transferred to lake water. Two could move about by movements of the body and tail. The other four showed little power of motion. These four larvæ and one of the two more motile ones did not grow much more in size but became quite abnormal in external form similar to those pictured in Plates II to V. One of the two more motile larvæ developed into a tapdole fairly normal in external form, although it died before any of the controls which were kept in the lake water.

Of the control ova in the lake water four eggs were unfertilized and nine developed into perfectly normal tapdoles which were kept alive for several weeks. Of the experiment ova on May I I eight unfertilized or undeveloped eggs were removed, leaving seventeen larvæ with slightly developed heads and very short caudal processes. On May I3 the control larvæ could swim for short distances. None of the experiment larvæ could do so. Externally the latter had begun to exhibit various abnormalities which beca me more marked from this period on. About a dozen of these larvæ were preserved on May 14. The others all died a few days later, i. e., in from ten to fourteen days after the 
exposure of the sperm. The external form of some of the larvæ preserved is shown on Plates II to V.

III, May I4. Unsuccessful because ova proved unripe. Between May 5 and May I3, owing to a spell of cool weather, no toads could be obtained.

IV, May I4. The day was very warm. At the end of the hour and half during which spermatozoa were exposed to the rays botk experiment and control spermatozoa were non-motile and proved incapable of fertilizing any ova.

V, May 15. Sperm exposed an hour and a half. A considerable proportion of the control ova were fertilized. Only a few of the experiment ova were fertilized. Of these only one developed past the early cleavage stages. On May 22, at three o'clock,p. m., this larva, which was small, unsymmetrical and ill-developed, appeared about to die. It was, therefore, killed and preserved. Microscopically it presented the features characteristic of the tadpoles developed from ova fertilized by irradiated sperm.

VI, May I6. Sperm exposed one and a quarter hour. At the end of this period neither irradiated nor control spermatozoa proved capable of motion or of fertilizing. The day was an exceedingly warm one.

VII, May 16. Sperm exposed one-half hour to the rays. Of the control ova only about 20 per cent were fertilized. These developed normally. Of the experiment ova only three or four per cent were fertilized. None of these developed past the gastrula stage.

\section{Structure of the Larva}

At the time of or soon after the hatching of the larvæ abnormal structural differentiation began to make an externally visible distinction between those experiment larvæ which developed best and the control larvæ. In the experiment larvæ the tails all showed more or less abnormality of form and the larvæ with a few exceptions proved incapable of swimming, although some were capable of irregular movements of the body and tail. In length the experiment larvæ did not grow much after this period. In width and thickness the growth was greater but was in large part 
due to abnormal distension of various regions with fluid. The external form mean while became most irregular. Thisirregularity of external form is more easily illustrated than described. See outlines on Plates II to V. At the period when the sketches were made of the larvæ here illustrated the control larvæ had the external form shown in the outline on Plate $I$. The rudiments of the hind legs were beginning to be externally visible.

The organs of the experiment larvæ show the same irregularity of form as that shown by the body as a whole. Wax model reconstructions of the organs of each individual larva which has been preserved and of a series of stages of the normal larvæ of the toad would be necessary for a thorough study of the abnormalities which exist in the experiment larvæ. It has not seemed worth while to make so elaborate a study because each experiment larva is affected in such an individual way that it seems improbable that broader generalizations could be drawn from such a study than from the simple inspection of the serial sections of the larvæ.

\section{Control Larva of the Size of the Experiment Larvæ}

The control larvæ at the period when the experiment larvæ began to show marked abnormalities in external form were about at the stage described by Marshall in his Vertebrate Embryology as characteristic of the tadpole of the frog shortly after hatching. The organs may be briefly described as follows:

Nervous System-The central nervous system is slightly more advanced than at the stage of development described by Marshall in the newly hatched tadpole of the frog. The forebrain extends anteriorly between the olfactory pits. The end brain is beginning to be divided anterior to the olfactory pit into two hemispheres. In the groove between these is a vascular plexus. The pineal body extends forward above the undivided portion of the forebrain. It is composed of cords of cells interlaced with capillaries. The optic stalks are patent near the neural canal but toward the optic cupsare narrow and are apparently partly filled by newly formed fibers. The infundibulum is large, its lateral walls are thick. The roof of the midbrain has begun to thicken. The floor of the fourth ventricle on each side is very thick. The 
spinal cord may be followed well into the tail. It gradually becomes narrow and more rounded as one passes posteriorly. The neural canal is relatively large.

Organs of Special Sense-The nasal pit is connected with the pharynx by a solid column of cells. The thickened lateral wall of the brain projects against the olfactory pit and the olfactory nerve is in process of formation. The lens of each eye is in contact with the ectoderm. Although differentiation of the lens is well under way it still contains a vesicular cavity. The sensory layer of the retina is thick and closely applied to the pigment layer. As mentioned above, the optic stalk near the optic cup is small and seems to contain nerve fibers.

Each auditory vesicle is a simple closed sac with a short blind diverticulum. The auditory ganglion consists of a mass of cells situated between the anterior portion of the auditory sac and the medulla.

Peripheral Nerves-The trigeminal ganglion is large. It is not in connection with the ectoderm. The ganglion of the facial nerve cannot be sharply distinguished from that of the auditory nerve. The glossopharyngeal and the vagus ganglia are well developed but it is difficult to trace the chief branches of these nerves for any considerable distance. The spinal ganglia consist of well marked groups of cells lying ventro-lateral to the spinal cord. The nerve fibers of the spinal nerves are beginning to form in the proximal spinal segments.

Alimentary Canal-The shallow stomodæum opens into the pharynx. The lips and jaws of the stomodxum are beginning to grow forward.

The broad pharynx communicates by gill slits with the exterior The external gills are fairly well developed. The opercular fold is beginning to be formed.

The anterior part of the lumen of the œsophagus is blocked up by epithelial cells. The pulmonary diverticula are small lateral outgrowths which extend but a short distance posteriorly from the œsophagus.

Passing back from the blocked region of the œsophagus the gut makes a curve to the left about the liver and pancreas, and then 
terminates in a mass of cells filled with yolk and presenting no well marked lumen. Toward the posterior end of the trunk a lumen appears in the dorsal region of this mass. This lumen may be followed to the anus.

The sinusoidal circulation of the liver is well established. The bile duct is of some length and opens into the intestine slightly to the left of the mid-line of the body. The anlage of the gall bladder may be seen below the bile duct.

The anlage of the pancreas is marked by a deeply staining mass of cells posterior to the anlage of the liver on the left side of the body. The ducts at this stage are not clearly marked in this embryo.

Heart and Blood Vessels-The heart is an S-shaped tube, the lumen of which is filled with blood. There are no well-marked trabeculæ in the ventricle. The main arteries and veins are filled with blood and may be readily followed. In general they seem to correspond with the diagrams of the blood vessels for the recently hatched tadpole given by Marshali (Embroylogy, p.I70, Figs. 77 and 78 ).

Reproductive Organs-The coiled tubules of the head kidney are surrounded by a vascular plexus. Distally the two Wolfian ducts have a common opening into the cloaca. They are patent throughout.

Skeleton--The notochord and a loose mesenchyme formed of anastomosing cells constitute the skeletal tissues of this embryo.

Muscles-In the region of the head the muscles anlages are marked by dense masses of tissue, in some of which specific differentiation has begun. In the region of the spinal cord the myotomes form a well differentiated segmental musculature on each side of the chorda dorsalis, the spinal cord and the spinal ganglia.

Control Larva of the Age of the Experiment Larvæ

The control larvæ, Plate I, at the period when most of the experiment larvæ were preserved for examination were about at the stage of development described by Marshall for the $12 \mathrm{~mm}$. tadpole of the frog. The organs may be briefly described as follows : 
Central Nervous System-The olfactory lobes extend between the nasal organs. They are beginning to be fused in the region shown in section $a$. Anterior to this they are more clearly separated and posterior to it the lobe on each side is continued into a well marked cerebral hemisphere. Section $b$ passes through the brain slightly anterior to the junction of the two lateral with the third ventricle. The anterior end of the choroid plexus is shown between the two lateral ventricles and above this the posterior portion of the pineal body. The latter extends forward for a considerable distance beneath the ectoderm. At this period it contains a small vesicular cavity. The lateral walls of the third ventricle are thick (section $c$ ). The optic stalk has been converted into an optic nerve but has a short patent lumen near the third ventricle. This does not appear at the level of section $c$. The infundibulum is large. The opening into it from the third ventricle is small, but beyond here it rapidly expands (section $d$ ). The optic lobes project dorsally on each side of the midbrain (section $d$ ) The cerebellum is marked by a slight thickening of the anterior margin of the roof of the fourth ventricle. The ventro-lateral walls of the medulla are very thick (section $e$ ). The folds of the choroid plexus are beginning to appear in its thin roof. The spinal cord is well developed and extends far back in the tail (sections $f, g$ and b). The Randschleier, in the region of the trunk, is as thick as the layer of cells surrounding the central canal.

Organs of Special Sense-Large nasal fossx extend from the exterior to the pharynx. The epithelium of the medial wall of each fossa is very thick (section $a$ ). Cæcal outgrowths are taking place from the posterior dorsal portion of each fossa. Bundles of nerve fibers may be traced from the lateral side of each olfactory lobe to the thickened epithelium of the corresponding nasal fossa.

The eyes (section $c$ ) are well developed. The several layers of the sensory part of the retina may be distinguished. A thin sclerotic coat is present. The well formed lens is separated by a distinct interval from the ectoderm.

The auditory vesicles (section $e$ ) are being divided by the ingrowth of septa into the various portions characteristic of the adult ear. The auditory nerve is undergoing rapid development. 
Peripheral Nerves-The ganglion of the trigeminal nerve is highly developed. In section $d$ a portion of it may be seen on each side of the midbrain. The main branches of the nerve may be followed for some distance from the ganglion. The ganglion of the facial nerve is still so close to that of the auditory nerve that no sharp line of division can be seen in the sections. The glossopharyngeal and vagus ganglia are likewise still difficult to differentiate from one another in the sections. The spinal ganglia are well differentiated. The motor and sensory roots and the main trunks of the spinal nerves may be distinguished without difficulty.

Alimentary Canal - The lips and beak are highly developed. Section $a$ shows on each side of the oral opening a section of the lower jaw tipped by an epithelial tooth. The operculum is attached to the ventral and right sides of the body posterior to the gills. Section $e$ shows the opercular cavity near the anterior end of the heart. The internal gills are of considerable size. Only traces of the external gills remain. Over the region of the heart the ventral wall of the pharynx gives rise to a medial projection which extends in a posterior direction in the pharynx. Near the tip of this the trachea arises as a solid column of cells from the ventral wall of the alimentary canal near the junction of the pharynx and osophagus. More distally two tubular pulmonary processes extend back one on each side from the trachea along the dorsal wall of the body cavity. These do not reach so far as the anlage of the pancreas. The cesophagusnarrows rapidly posterior to where the trachea is given off. It diverges at this period toward the right side of the body (see section $f$, immediately in front of and at the left of the chorda dorsalis). It joins the stomach in front of the pancreas. In section $f$, on the left side of the figure (right side of the body), the stomach is shown cut through in two places and between these two sections of the stomach the anterior portion of the pancreas shows on each side. The two regions of the stomach here shown are joined together anterior to this section. The ventral portion is joined with the œesophagus posterior to the level of the section. The dorsal portion of the stomach shown in this section passes posteriorly into a much coiled intestine. Part of the coils of the intestine pass ventral to the heart, anterior to the 
liver. The liver and gall bladder are highly differentiated. The posterior end of the liver and the bile duct are shown between the œsophagus and stomach in section $f$. The gall bladder lies dorsal to the liver somewhat anterior to the level of this section. The entrance of the bile and pancreatic ducts into the gut takes place considerably posterior to this level. The anus in this embryo passes out between the anlages of the posterior limbs (section $g$ ).

Heart and Blood Vessels - The heart is much larger than that in the control embryo previously described. The ventricle is crossed by large trabeculæ (section $e$ ). The auricle is beginning to be divided into right and left halves. The blood vessels are dilated with blood. The vessels seem to correspond with those described for the $12 \mathrm{~mm}$. tadpole by Marshall (Embryology, Fig. 76 , p. I66).

- Genito-Urinary Organs-The tubules of the head kidney are greatly coiled. The tubules of the mesonephros are differentiated near the cloaca. More anteriorly the anlages of these tubules consist of dense masses of cells. The genital folds are not prominent.

Skeleton-The differentiation of the vertebræ has scarcely begun in this embryo. The chief cartilages of the skull have appeared (see Marshall, Embryology, p. 262, Figs. 90, 9I and 92). A moderate amount of mesenchyme surrounds the different organs.

Muscles-The chief muscles of the head are clearly differentiated. In the trunk the myotomes are larger than at the preceding stage and the muscle cells are more highly developed.

The abnormalities exhibited by the experiment larvæ may be illustrated by a few typical examples.

\section{Larvæ No. I, Experiment II, Plate II}

External Form-This embryo exhibits a marked dorsal flexion of the body near the middle of the trunk, so that the long axis of the tail is at right angles to that of the anterior portion of the trunk and the head. The bend seems due largely to an abnormal dilatation of the hind-gut. The head is quite irregular in shape, the deformity of outline being due to great abnormality in the 
internal structures. Posterior to the mouth the sucker is well developed on each side ( $\operatorname{section} b$ ).

Central Nervous System-The brain ends anteriorly in a hollow rounded protuberance from which a vesicular ventricle projects on each side (section $a$ ). The brain does not extend anteriorly to the olfactory pits. The walls of the telencephalon and the hemispheres are irregular in thickness and the cells and fibers are very abnormally disposed. Many pigmented and appparently degenerate cells lie in the walls of the third ventricle and free in the ventricle. The pineal gland lies between the roof of the third ventricle and the ectoderm in a region posterior to section $a$. It has a thin wall and a hollow central cavity containing scattered cells which show evidences of degeneration. As one passes back the neural canal becomes much dilated. In the region of the optic stalk it is thin-walled (section $b$ ). The hypophysis is somewhat dilated but is relatively normal in structure (section $c$ ). The roof of the midbrain is rather thin. In the region of the ears the left side of the brain is much less developed than the right side (section $d$ ) and posterior to the ears for a considerable distance the left side of the neural tube consists of hardly more than an irregular membranous wall. Near the middle of the trunk the spinal cord is more symmetrical, but posteriorly it is once more undeveloped on the left side (section $g$ ).

Organs of Special Sense--The nasal pits on each side are connected with the pharynx by columns of cells (section a) which show near the pharynx an imperfect lumen. The eyes are irregular in form (section $b$ ). A cornea has been differentiated. The sensory portion of the retina is poorly developed. The lumen of the optic stalk is dilated and extends into a space between the two layers of the retina. There are no nerve fibers (section $b$ ). The pigment cells of the pigment layer are irregularly disposed and project out into the neighboring tissues. The auditory saccule consists of a rounded pouch with a dorsal diverticulum (see d). The auditory ganglion is clearly marked but no nerve fibers can be distinguished.

Peripheral Nerves-The cells of the ganglion of the trigeminal nerve are large and well differentiated. Nerve fibers cannot 
readily be followed. The ganglia of the ninth and tenth nerves are present on the right side only and are rudimentary. Rudimentary spinal ganglia are present except where the left side of the spinal cord is defective. No nerve fibers can be distinguished.

Alimentary Canal--Lips and beak are differentiated, though abnormal in form. Section a passes through the lower jaw and lower lip. The oral opening into the pharynx is large. The internal gills are irregularly developed and contain no blood vessels. The œesophagus is patent and extends to the left into a thickwalled stomach. In the latter part of its course the lumen is divided into three flues, all of which open into the stomach (sections $e$ and $f$ ). The tracheo-pulmonary process is short, does not branch and has a slight lumen. The liver is developed posterior to the region of the heart and ventral to the stomach (section $f$ ). A few blood corpuscles can be seen in the much dilated capillary spaces of the liver. The pancreas is developed on the left side of the body posterior to the stomach. It consists of columns of cells. From the stomach the gut passes into an irregular group of coiled intestines, situated well on the left side of the body in the anterior region of the body cavity (section $e$ ), but in the middle more posteriorly (sections $f$ and $g$ ). The hind gut is greatly distended. The anus seems to be occluded. The epithelium over the anus extends outward with irregular branching processes.

Circulatory System-The heart is occluded and contains no blood. The only blood vessels clearly distinguished are a portion of the dorsal aorta, the mesenteric artery, and a few venous sinuses in the liver. In these vessels a few blood corpuscles are scattered about.

Genito-Urinary System-The tubules of the pronephros are much dilated. There are a few glomerular tufts but these contain no blood vessels. The Wolfian tubules are abnormally dilated (sections $e, f$ and $g$ ).

Skeleton and Connective $\mathcal{T}$ issue-The connective tissue is in most regions excessive in amount. Pigment cells are irregularly scattered about. Most of the cartilages of the head seem to be present but the tissue is not thoroughly differentiated and there are some abnormalities of form. The auditory capsule is not 
differentiated. The chorda dorsalis is fairly regular in form except at the anterior end, where some of the cells seem completely to have disappeared, and in the region of the medulla, where it is asymmetrical in places.

Musculature-A number of the muscles of the head are fairly well developed. The individual muscle cells are in some instances highly differentiated. The myotomes are fairly normal except next the undeveloped region of the spinal cord on the left side.

Skin-In several places there are villus-like outgrowths of epithelium.

Larva No. 2, Experiments II, Plate III

External Form-The caudal extremity of the embryo bends sharply in a dorsal direction. The body cavity is enormously distended, although the alimentary canal is but slightly developed (see sections $c$ to $i$ ). In these sęctions the ventral wall of the body cavity has collapsed, owing to the action of the fixing fluids. The head is exceedingly irregular in shape, owing to the imperfect development of the organs of special sense and the abnormal accumulation of a loose mesenchyme. The mouth opens on the back of the head anterior to the anterior nares. Apparently there is no sucker. Along the dorsal margin of the posterior end of the body and the tail, folds of tissue project (sections $b$ and $i$ ).

Central Nervous System-The ventral end of the central nervous system consists of a thin-walled dilated sac which does not extend as farforward as the nasal fossx. Sections $a, b$ and $c$ show no trace of it. Sections $d, e$ and $f$ show the abnormal condition of the walls of the neural tube. There is no fibrilar framework (Randschleier). The cells are irregularly placed; many of them show evidences of degeneration and not a few lie free in the neural canal. The pineal gland is a small vesicular pouch, the walls of which are composed of cells which exhibit degeneration. The infundibulum consists of a thin-walled projection from the ventral portion of the neural canal. Section $d$ shows the entrance into it. The spinal cord consists of a round thin-walled tube in which no specific differentiation has taken place. 
Organs of Special Sense-The nasal fossæ are patent but irregular in form (sections $b$ and $c$ ). No olfactory nerve can be distinguished. The eyes are very rudimentary (section $d$ ). The lens consists of a small round clump of cells. The optic stalk is patent and the pigment and sensory layers of the retina are separated by a space connected with the lumen of the eye stalk. The sensory layer consists of a thin membrane of partly degenerate cells. The cells of the pigment layer are irregular in outline. The auditory vesicles are small round sacs from each of which a short dorsal diverticulum extends. The auditory nerve is not distinguishable.

Peripheral Nerves-The ganglion of the trigeminal nerve is partly developed. Those of the ninth and tenth nerves are not distinct. No spinal ganglia can be distinguished with the exception of one small group of cells in the mid-thoracic region.

Alimentary Canal-An irregularly shaped mouth extends from the dorsal surface of the head to the pharynx. Its margis are surrounded by folds of tissue (section $a$ ). The pharynx is dilated near the mouth (section $b$ ). Posteriorly it is flattened from front to back (sections $c$ and $d$ ). The gill clefts are patent. From the septa which partially close them irregular outgrowths arise (section $d$ ). The oesophagus passes posteriorly from the right side of the pharynx (section $e$ ). At the left of the origin of the osophagus there is a mass of cells, flat in cross section, which is continued for some distance along the dorsal wall of the body cavity (section f). This represents the tracheo-pulmonary anlage. The œsophagus passes into the stomach at the left of the liver (section $e$ ). The gut curves in front of the pancreas (section $f$ ), whence it is continued into a straight gut which about the middle of the trunk exhibits a distinct lumen that is continued with some interruptions to the rectum (sections $b$ and $i$ ) and through the anus to the exterior. In addition to the main lumen several irregular tubular spaces occur in the mass of cells which compose the gut. The greatly dilated body cavity extends far forward beneath the pharynx. The liver is partially differentiated, extends forward beneath the pharynx and posterior to the rudiment of the heart has a few blood sinuses containing blood corpuscles. The pancreas is partially differentiated posterior to the liver and dorsal to the stomach. In 
section $f$ it may be seen between the gut and the tracheo-pulmonary process.

Heart and Blood Vessels-The heart apparently consists of a thin-walled tube which has been ruptured. The only blood vessels which can be made out in the embryo are irregular sinuses containing a small number of blood corpuscles.

Genito-Urinary Organs-The pronephric tubules are rudimentary and are irregularly drawn out in the distended wall of the body cavity (section $f$, on the right side of the section). The Wolfian ducts cannot be followed uninterruptedly to the cloaca. They lie far out in the body wall on each side. In places they are dilated, in places apparently missing.

Skeleton and Connective Tissues-The anterior end of the chorda is small and defective (section $f$ ). In the spinal region it is relatively normal (sections $b$ and $i$ ). There is an excessive amount of loose mesenchyme throughout the body, especially in the region of the head. A few of the cartilages of the head are developed, though apparently not perfectly normal in form.

Musculature - In the head a few groups of partly differentiated muscle cells indicate muscles. The outlines of the trunk myotomes are not distinct. The muscle cells are more scattered than normal, owing apparently to their being forced apart by the invasion of fluids and mesenchyme.

Skin-There are numerous places in which the epithelium gives rise to finger-like projections. The most marked of these is the dorsal margin of the trunk and the tail.

\section{Larva No. 3, Experiment II}

External Form-The posterior half of the body, including the tail, bends sharply in a dorsal direction. This is due to a great dilation of the hind gut. The head is rounded and swollen and it is difficult to make out clearly the specific characters of the tadpole head. The sucker is rather flat.

Central Nervous System-The central nervous system ends anteriorly in two distinctly separated olfactory lobes into which the lateral ventricles extend but a short distance. The walls a re abnormally differentiated and contain both cells and fibrous tissue, 
(Randschleier). There is no pineal gland but the roof of the third ventricle projects inward in such a way as to suggest an inverted pineal gland. It is different from the inversion which accompanies the choroid plexus. The ventral wall of the brain is thick where the optic stalks arise. The infundibulum is large and contains many desquamated cells. The roof of the midbrain is thin, although there are some evidences of the rudiments of the optic lobes. The medulla is relatively normal. A considerable mass of tissue, resembling yolk cells, lies free in the fourth ventricle. The proximal part of the spinal cord is fairly well developed. Posteriorly in places the spinal cord is irregular in form.

Organs of Special Sense and Peripheral Nerves-On the right side a nasal fossa extends from the nasal pit to the pharynx. On the left side a column of cells with an imperfect lumen does not quite reach the pharynx. Near the pharynx is gives off a lateral process. The optic stalk is patent on each side and the cavity extends between the pigment and sensory layers of the retina. The sensory layer is not specially differentiated. The cornea is closely applied to the front of the sensory layer and lies at some distance from the ectoderm. The auditory vesicles are somewhat simple sacs with dorsal diverticula. The auditory nerve may be followed into the brain. The sensory ganglia are for the most part fairly well developed. The peripheral nerves cannot be followed.

Alimentary Tract--There is a free opening into the pharynx. This is surrounded by imperfectly developed lips and jaws. On the lips and the jaws are numerous imperfect teeth. Internal gills are fairly well developed on the left side but on the right side form a dense mass fused with the operculum. The opercular cavity does not extend ventral to the pericardium. The osophagus is nearly occluded by epithelial cells. From it a solid cord of cells passes posteriorly and represents the pulmonary anlage. As the cesophagus is continued into the stomach the alimentary canal swings to the left of the liver and pancreas. The gut then passes to the right across the front of the body, then anteriorly and finally curves back and passes into a portion of the gut which is much distended and extends posteriorly for some distance, then takes 
several coils forward and finally passes back into the rectum. This is greatly dilated and partly coiled. The anus is small and apparently partly stopped up by mucus. The ventral wall of the body cavity is strikingly thick, not only in front of the heart but also over the entire abdomen to the anus.

Heart and Blood Vessels-The heart is thin-walled but fairly well formed. There are some trabeculæ in the ventricle. The pericardial cavity is small, owing to the great amount of mesenchyme in the body wall. Some, at least, of the chief blood vessels are present and contain a considerable amount of blood.

Genito-Urinary Organs - The tubules of the head kindey are irregular in form and are much dilated in places. The Wolfian ducts may be followed to the cloaca. Near the cloaca the anlages of the tubules of the mesonephros may be seen.

Skeleton and Connective Tissue-The chorda is relatively normal. An excessive amount of mesenchyme is present, especially in the region of the head. In the head most of the cartilages are fairly well developed.

Musculature - In the head the muscles are fairly well differentiated. The myotomes are fairly normal although the cells are somewhat more scattered than usual.

Skin-In places irregular finger-like processes of the epithelium project from the body.

\section{Larva No. 4, Experiment II, Plate IV-A}

External Form-The tail is a mere rudiment. The ventral part of the body is much swollen, owing to distention of the body cavity. The head is small and deformed. The sucker is rather flat (section a).

Central Nervous System-The neural tube ends anteriorly in two thick walled olfactory lobes. The right one is shown on the left side of section $a$. The cells in the walls are irregularly placed and many exhibit signs of degeneration. The Randschleier is not normally disposed. There is a small pineal body with a narrow lumen and thick walls composed of cells not specifically differentiated. The optic lobes are partially differentiated. The infundibulum has a thin wall but contains in its cavity a large mass 
of cells. The lateral walls of the midbrain are excessively thick and the lumen of the aqueduct is narrow. The ventral wall of the medulla is irregular in outline in places (section $b$ ). There are many desquamated cells in the fourth ventricle. The spinal cord is greatly deformed in most regions and in many cases shows no central canal (sections $d$ and $e$ ). In the midthoracic region it is fairly normal in form. . The spinal cord does not extend into the rudimentary tail.

Organs of Special Sense-The nasal fossæ are patent. The medial wall of each fossa is thin (section $a$ ). The optic stalks are patent. The pigment layer of the retina is separated from the sensory layer. The latter is not specifically differentiated. A lens rests against the sensory layer (section $a$ ). The auditory vesicles are simple sacs with dorsal diverticulæ.

Peripheral Nerves--The sensory ganglia of the fifth, seventh and eighth, ninth and tenth nerves can be distinguished. The nerves can be followed but a short distance. Spinal ganglia are present in the midthoracic region where the spinal cord is fairly normal in form, but are not present elsewhere.

Alimentary Canal-The mouth is patent. The jaws and lips are partially differentiated. The gill slits are patent. The internal gills are rudimentary in form and contain no obvious blood vessels. The operculum is only partially differentiated. There is no opercular cavity in front of the heart. The tracheo-pulmonary anlage is a short branched column of cells. The osophagus is composed of dense tissue in which several irregular spaces suggest a coiled tube (section c). The stomach curves about the left side of the anlage of the liver (see right side of section $d$ ). The liver is highly differentiated (section $c$ ) and is connected by ventral and dorsal mesenteries to the walls of the body cavity. The large blood spaces in the liver contain traces of blood. The bile duct is large. The pancreas is not specifically differentiated but its anlage is marked by a mass of yolk cells. The gut curves from left to right in front of the anlage of the pancreas and then turns distally. Beyond the region of the pancreas the gut passes nearly straight back to the anus. The ventral portion is thick and filled with yolk cells as in young larvæ. The anus opens on 
the right side of the body between the rudimentary tail and the body cavity (section f). "The body cavity is greatly distended (sections $d, e, f$ ).

Heart and Blood Vessels-The heart is a simple S-shaped tube. The ductus arteriosus is patent; the ventricle has very thick walls, a small lumen and no trabeculæ. The sinus venosus and the auricle are thin-walled. There are a few blood corpuscles in the lumen of the heart. Mere traces of blood vessels are visible.

Genito-Urinary Organs-The tubules of the pronephros are much dilated. They lie in large spaces which here and there contain a few blood corpuscles (section $d$ ). The Wolfian ducts are much distended (section $e$ ).

Skeleton and Connective $\mathcal{T}$ issues - The chorda is relatively normal in structure. There is an excessive amount of connective tissue, especially in the region of the head. The cartilages of the head are partly differentiated. There are no auditory capsules.

Musculature-The muscles of the head are partially differentiated. The myotomes are relatively fairly well developed (sections $d$ and $e$ ).

\section{Larva No. 5, Experiment II}

External Form-The tail curves dorsalward. The abdomen is distended. The head is somewhat irregular in form. The sucker consists of a short projection on the right side of the body.

Central Nervous System-Anteriorly there are two small olfactory lobes. The lateral ventricles extend but a short distance into each. The pineal body is round and has a slender stalk. The cells composing the body are more or less scattered, although the outer wall of the body is fairly smooth. The lateral walls of the third ventricle are thick and show a fairly normal differentiation into cells and Randschleier. The hypophysis has a very thin wall. The optic lobes are not differentiated. The fourth ventricle is much distended. The walls of the medulla contain many degenerated pigment cells.

Organs of Special Sense-The tissue of the medial wall of each nasal fossa contains many degenerated pigment cells. The pigment layer of the retina is separated from the sensory layer. 
Neither optic stalk shows a lumen. The sensory layer of the retina shows much degeneration. The lens rests against it. The auditory vesicles are simple.

Peripheral Nerves-The sensory ganglia of the head and the nerve branches may be followed better than in most of the experiment larvæ. The spinal ganglia and nerves are less definite.

Alimentary Canal-The mouth is patent and is surrounded by partially differentiated jaws and lips. The internal gills are imperfectly developed. The operculum extends but a short distance posteriorly. The œsophagus is occluded with cells. The tracheopulmonary process is short and branched. The œsophagus continues to the left into the stomach. The gut curves ventrally to the right in front of the pancreas, then anteriorly on the right of the liver and then bends back in a posterior direction. The liver is well developed and contains large sinusoidal spaces. A very few blood corpuscles appear to be contained in these spaces. There is a large gall bladder. The pancreas is also well developed. The gut, immediately posterior to the pancreas, is greatly distended and beyond the region of distention exhibits several partial coils. The anus is patent. In the body cavity many multi-nucleated cells can be seen. The walls of the body cavity are excessively thick.

Heart and Blood Vessels-The heart is S-shaped. The ductus arteriosus is solid. There is a small lumen in the ventricle. The sinus venosus is thin-walled. In places blood vessels containing a small amount of blood may be seen, but the vascular system is imperfectly developed.

Genito-Urinary Organs-The tubules of the pronephros are greatly distended and lie in large spaces in which some blood corpuscles may be seen. The. Wolfian ducts are greatly distended near the pronephros but not much more distally. That on the left side is much smaller than that on the right.

Skeleton and Connective $\mathcal{T}^{\prime}$ issues-The chorda dorsalis is moderately normal in structure. In the sections it is shrunken. There is an excessive amount of connective tissue, especially in the region of the head and in the wall of the body cavity. The cartilages of the head are fairly well developed. 
Musculature-The muscles of the head are well differentiated. In places the spinal myotomes are fairly normal; in places the cells composing them are much scattered.

$S k i n-T h e$ epithelium shows irregular projecting processes in many places.

\section{Larva No. 6, Experiment II, Plate V}

External Form-The long axis of this embryo is nearly straight. The head appears much crumpled. The mouth is a large cavity bounded by irregular folds of tissue. There is a small semicircular sucker back of the oral opening.

Central Nervous System-The brain is anteriorly much dilated (section $a$ ) and extends to the anterior extremity of the head. The neural wall is very thin and the central cavity is filled with degenerated cells. The dorsal wall of the forebrain in places is fused to the ectoderm (section $b$ ). There are no visible traces of a pineal body. The ectoderm is irregularly thickened where it comes in contact with the brain and in some places is very thick. In one place a long column of ectoderm cells extends in between the ectoderm and the brain (right side of section $b$ ). The dorsal wall of the brain on each side in the region of the eyes is greatly thickened. The midbrain is most irregular in form and gives rise to several vesicular processes of uncertain nature. The walls of the midbrain are thin and the central canal is large. The medulla is most abnormal in form (sections $c$ and $d$ ). The dorsal part of the fourth ventricle is curiously dilated. The spinal cord is more normal in form than the brain although it also is much deformed in places.

Organs of Special Sense-The only trace of nasal epithelium is a collection of cells between the dilated pharynx and the ectoderm in the anterior part of the head shown on the right side of section $a$. The eyes are very abnormal. The optic stalk is dilated so as to make a direct opening from the neural canal to the back of the sensory layer of the retina. There is no trace of specific differentiation in this layer (section $b$ ). Where the optic stalk approaches nearest to the ectoderm a lens has been differentiated. This is still in contact with the ectoderm and consists of 
a group of little differentiated ectoderm cells. The auditory vesicles are simple in form, thick-walled, and resemble those newly formed in the embryo.

Peripheral Nerves-Mere traces of the sensory ganglia of the cranial and spinal nerves can be seen. Nerve fibers are not well marked.

Alimentary Canal-The mouth is a large opening into the pharynx. The opening is irregular in outline and its boundary presents mere traces of a beak and lips. The pharynx is dilated anteriorly (section $a$ ), but over the cardiac region is flat and bent to conform to the dilated pericardial cavity. The gill clefts nowhere open to the exterior but instead a re laterally stopped up by masses of epithelial tissue (section $c$ ). No gills a re specifically differentiated. The œsophagus is filled with epithelial cells. The tracheopulmonary process is rudimentary. The cesophagus passes directly back into a primitive intestine. Neither liver nor pancreas seem specifically differentiated, although the anlages of each are represented by masses of yolk cells (section $e$ ). The gut consists of a mass of cells which extends in a fairly straight direction from the œsophagus to the anus. Anteriorly it shows some tendency to form convolutions, and in the mid-body region it curves slightly toward the right side of the body. For the greater part of its course no lumen is present.

Heart and Blood Vessels-The pericardial cavity is very thickwalled anteriorly but is relatively large. More distally the ventral wall is thin (section $c$ ). Traces of a heart can be seen (sections $c$ and $d$ ). This forms a slightly $S$-shaped structure with thin-walled ductus arteriosus and sinus venosus (section $d$ ) and a more solid ventricle (section c). There is no blood in the heart cavity. No definite blood vessels can be made out in the embryo.

Genito-Urinary Organs-The tubules of the pronephros are much dilated. The Wolfian ducts can be traced only part of the way to the anlage of the cloaca. In the distal part of their course they are curious flat tubes (section $f$, on each side of body).

Skeleton and Connective Tissues-The chorda dorsalis is slightly asymmetrical in places. The connective tissue is excessive, especially in the head. The cartilages of the head are not distinct. 
Musculature-Mere traces of muscles are found in the region of the head. The more anterior myotomes consist of rounded masses of cells on each side of the chorda but not in contact with this (section $e$ ). In the center of the trunk and in the tail they are somewhat more normal in form.

Skin-Projections of epithelium may be seen on the dorsal margin of the tail (section $g$ ) and at the side of the ventral wall of the body cavity (section $e$ ). There are curious subcutaneous vesicles on each side of the head posterior to the sucker. Section $b$ shows one of these at the left of the section.

\section{Larva No. 7, Experiment II, Plate IV-B}

External Form-The tail is short and stubby and curves dorsally. The heart is shrunken and irregular in outline. The sucker is apparently fairly normal.

Central Nervous System-Two well separated olfactory lobes project forward as far as the nasal fossa and each is in contact with the medial wall of the corresponding nasal fossa (section $a$ ). The tissues of the olfactory lobes are partially degenerated. The lateral ventricles are very small. The lateral walls of the third ventricle are thick and partially differentiated (section $b$ ). The pineal gland projects above the third ventricle and its tissue is partly degenerated. The infundibulum is small and thin-walled. The lateral walls of the mid-brain are thick and project inward so as to nearly obliterate the aqueduct. The hind-brain is relatively normal, although flattened from front to back (sections $c$ and $d$ ). The spinal cord in places is fairly normal, in places the cells from the walls of the neural tube fill or nearly fill the central canal.

Organs of Special Sense-The nasal organs are fairly well differentiated. They lie, relative to the brain, posterior to the normal position. The pigment layer of the retina is separated by a space from the sensory layer. The latter is not well differentiated. The optic stalk is not patent but contains no nerve fibers. A lens is present. The auditory vesicles are simple in form.

Peripheral Nerves-Cranial and spinal ganglia are moderately well developed. The nerve fibers cannot be readily traced. 
Alimentary Canal-The mouth is open. Lips and jaws are rudimentary. The pharynx is dilated and contains a sac-like protrusion through its floor from the pericardial cavity (section $c$ ). The gills are rudimentary and are contained within a cavity on each side which is formed by an opercular fold open behind (section $d$ ). The œsophagus has a lumen into which irregular vesicular spaces open. The tracheo-pulmonary process is short. The gut passes to the left of the liver and pancreas, then curves across the body in front and finally extends straight back. The lumen is not distinct. Neither liver nor pancreas is well differentiated The body cavity is greatly dilated.

Heart and Blood Vessels-The heart is an S-shaped tube. The ductus arteriosus and ventricle are thick-walled; auricle and sinus venosus are thin-walled. There is a slight amount of blood in the lumen. The pericardial cavity projects into the mouth, pushing the floor of the pharynx ahead so that the heart comes to lie literally in the mouth. The only definite blood vessels are two vessels which appear to be posterior cardinal veins. These are dilated and anastomose with one another in several places.

Genito-Urinary Organs-The tubules of the pronephros are greatly dilated. The Wolfian ducts are irregular in form. That on the right side appears to be missing in places.

Skeleton and Connective $T$ issues - The chorda dorsalis is apparently normal. There is an excessive amount of connective tissue. Some of the cartilages of the head are fairly well differentiated.

Musculature-Some of the muscles of the head are fairly distinct. The myotomes are moderately normal, although in places the muscle cells are somewhat scattered.

Skin-In the region of the head there are especially large masses of projecting epithelium (section $a$ ).

\section{Larva No. 8, Experiment II}

External Form-The long axis is fairly straight. The general appearance is that of a normal embryo soon after the tail has grown out. The tail, however, is somewhat shrunken. The sucker is fairly normal. 
Central Nervous System-The olfactory lobes extend forward between the nasal fossæ. The tissue of the olfactory lobes is somewhat degenerated. The pineal gland consists of a rounded hollow vesicle with a short much dilated stalk. The ventral wall of the third ventricle is abnormally thick. The infundibulum is relatively normal. The walls of the midbrain are also fairly normal but contain some degenerated pigmented cells. The optic lobes are beginning to be differentiated. The hindbrain and spinal cord are relatively normal.

Organs of Special Sense-The medial walls of the nasal fossa are thick but contain many pigmented and degenerated cells. The eyes are very abnormal. The optic stalks are greatly distended. The pigment layer of the retina is irregular. The sensory layer consists of a mass of degenerated cells. The lens is differentiated. The auditory vesicles are simple in form.

Peripheral Nerves-The sensory ganglia are moderately well developed but the cells are many of them abnormal. Nerve fibers cannot be readily followed.

Alimentary Canal--The mouth is open. Lips and jaws are clearly marked, although not highly developed. Gill slits are patent, but the gills are not well developed and seem to contain no blood vessels. Opercular folds extend over the anterior portion of the gill region on each side. The œsophagus has a lumen. The tracheo-pulmonary process is short and branched. The stomach lies at the left of the liver anlage. The gut extends straight back. Neither liver nor pancreas is well developed, although masses of cells indicate their anlages. No blood spaces are found in the liver.

Heart and Blood Vessels - The heart consists of an S-shaped tube, but the walls are not normally differentiated. There is some blood in the ductus arteriosus. There are apparently a few blood vessels present but there is no well developed vascular system

Genito-Urinary Organs-The tubules of the pronephros are slightly dilated.

Skeleton and Connective $\mathcal{T}$ issues-The chorda dorsalis is relatively normal. The cartilages of the head are fairly well developed. 
There is a slight increase over the normal amount of connective tissue in the body. The pigment cells are abnormally scattered about.

Musculature-The muscles are fairly well differentiated in the head. The more anterior of the myotomes are fairly normal but in the posterior half of the embryo they are not well developed.

Skin-In many places the skin shows abnormal outgrowths especially about an irregular opening. into the body cavity.

\section{SUMMARY AND CONCLUSIONS}

Toad spermatozoa removed from the body begin to lose both motility and fertility within half an hour. Both motility and fertility last much longer on cool than on warm days and somewhat longer in unexposed than on spermatozoa exposed to the Roentgen rays. On cool days the power of fertilizing lasts in some of the spermatozoa over two hours. When only ten or fifteen per cent of the control eggs are fertilized as a rule few or none of the eggs placed with the exposed sperm are fertilized.

When only a few eggs are fertilized by the exposed sperm as a rule these eggs do not develop beyond the gastrula stage, but occasionally one may develop into an abnormal tadpole.

When the spermatozoa have been well exposed to the rays and yet are still capable of fertilizing a considerable number of eggs, the eggs thus fertilized develop at first apparently normally or even better than the control, but beyond the gastrula stage the development begins to become retarded and at the time of hatching, as the tail begins to grow out, marked deformities appear in the larvæ. These deformities are visible externally and are still more striking when the internal structure is examined. The illustrations given on Plates II to V illustrate these deformities more readily than they can be described in words. While they vary considerably there are certain features characteristic of most of the tadpoles.

\section{General Development}

Growth of the tadpole is inhibited beyond the stage which intervenes between hatching and the time when it should begin to 
swim. Thus when the control tadpoles of the same age as the experiment tadpoles are equivalent in general form to the $12 \mathrm{~mm}$. tadpole of the frog described at some length in Marshall's wellknown text-book, the development of the control tadpole is, as a rule, more nearly similar to the newly-hatched tadpole of the frog described by Marshall.

\section{External Form}

The head is usually abnormal in shape, the anterior end appearing shrunken. The colom is in many of the tadpoles abnormally distended. The tail is usually short, more or less deformed and is often bent in a dorsal direction.

\section{Internal Structure}

The vascular system is little developed in any of the experiment embryos. The heart usually is S-shaped but is rudimentary in form and may have no continuous lumen. In some embryos the wall of the ventricle is thickened by muscle cells but in none are there strong trabeculæ in the ventricle. The chief arteries seem in none of the embryos to be completely developed, although in some there are here and there traces of them. The chief veins are likewise in none of the embryos completely developed although in one embryo the cardinal veins are large. In the liver the capillaries are sometimes well, sometimes but slightly developed. There are relatively a very few blood corpuscles in any of the embryos. These lie in some of the scattered vascular anlages. It is uncertain whether the blood had circulated in any of the embryos, but in some of them it is fairly certain that no circulation was established. In all of the embryos the spaces in the tissues indicate a considerable amount of lymph either free in the tissues or confined in lymph vessels.

Of the central nervous system the brain is the part most constantly and deeply affected, but the spinal cord in many of the embryos is markedly deformed. The abnormalities consist partly of failure of development or tissue differentiation, partly of irregular growth of tissue, pigmentary degeneration of nerve cells and the 
filling of the central canal with partially degenerated cells. In one embryo the hind brain and anterior part of the spinal cord are exceedingly rudimentary on one side.

Of the organs of special sense the eye exhibits the greatest deformities. The nose and ear are as a rule rather rudimentary than markedly deformed. The eye, however, usually shows a patent optic stalk connecting with a space between the pigment and sensory layers of the retina, a lack of differentiation in the sensory layer, and a more or less highly differentiated lens resting against the sensory layer.

The abnormalities in the alimentary canal are exceedingly variable and may affect any or all parts. The mouth is in all instances patent, the lips and jaws rudimentary. The pharynx and gills vary much in structure in the different embryos. As a rule there are traces of internal gills and of the opercular folds but the gills, owing to lack of development of the vascular system, are rudimentary. The osophagus is patent in some, closed in other of the embryos; the stomach as a rule lies at the left of the anlages of the liver and pancreas. The latter structures are seldom highly developed. The rudiments of the lungs are slightly developed. The intestines may be more or less coiled, but are in none of the embryos highly developed and in some are very rudimentary. In many embryos the abdominal cavity is greatly distended while the gut is rudimentary.

The pronephric tubules are usually greatly swollen in places and this dilatation is also frequently found in the Wolfian ducts. There are seldom distinct traces of the metanephric tubules.

The myotomes, when not well developed, usually consist of muscle cells somewhat scattered about in the surrounding mesenchyme. The muscles of the head are usually more or less differentiated.

The mesenchyme of the embryos is considerably greater in amount than in normal tadpoles. The cells seem to be spread apart by fluids in the tissues. The cartilages of the head and the chorda dorsalis are relatively normal.

The ectoderm in most of the tadpoles shows in places outgrowths of an irregular nature. These may be extensive villus-like pro- 
cesses. In one instance marked ingrowth of processes from the ectoderm occurred.

The cells of the tissues appear for the most part clear in outline. Many of the cells of the central nervous system seem to have undergone a pigmentary degeneration. Numerous cells in most of the tissues show mitotic figures. I have been unable satisfactorily to determine whether or not there are abnormalities in these figures. There is an abnormal number of cells with two or more nuclei. A striking feature of the experiment embryos is the irregular distribution of the pigment cells. They are much more irregularly distributed through the tissues than in the normal embryos.

There is a striking resemblance between tadpoles which develop from ova fertilized by sperm exposed to the Roentgen rays and the tadpoles exposed directly to radium irradiation by Schaper ${ }^{81}$ This shows clearly that injuries produced in nuclei may be carried through many generations of cells in an individual and finally give rise to deformities corresponding with those due to direct irradiation. Bohn $\mathrm{n}^{82}$ found that the rays of radium rapidly enfeeble or kill the sperm of strongylocentrotus lividus, but that the eggs appear more fertile after exposure. He does not describe the effect of exposure of the germ cells on subsequent development.

Herbst $^{83}$ found by treating the sperm of sea-urchins with fresh water, alkalies and potassium-free salt water and then fertilizing ova of a different species with the sperm thus injured that the ova sometimes developed as if injured but that there was no evidence that the specific hereditary factors transmitted by the spermatozoa were altered. Further studies are necessary to determine if the hereditary factors carried by the sperm may be specifically influenced by irradiation. D. T. Macdougals has shown that in some plants mutations may be produced by injecting radium preparations, sugar solutions and solutions of calcium nitrate and of zinc sulphate into the ovaries. This most important work sug-

\footnotetext{
${ }^{81}$ Schaper: Anat. Anzeiger, Ixv, p. 298, 1904. Levy: Archiv f. Entwicklungsmechanik, xxi, p. I3०, 1906 .

${ }^{82}$ G. Bohn: Comptes Rendus de l'Acad. des Sciences, Paris, crxsv, p. I012, 1085, 1903.

${ }^{83}$ Herbst: Archiv für Entwicklunsmechanik der Organismen, xxi, p. 293, 1906.

"MacDougal; The Popular Science Monthly, September, 1906, p. I6.
} 
gests that the hereditary factors contained in spermatozoa might be so altered as to produce specific variation in the individuals springing from ova which they fertilize.

The effects of altering the normal course of development of vertebrates by electrical, magnetic, chemical or mechanical agents applied to the whole organism, have been shown by Dareste, ${ }^{85}$ Féré ${ }^{86}$ Roux, ${ }^{87}$ and many others, to be seldom confined in a specific way to an organ or group of organs, although some organs, like those composing the nervous system, are especially sensitive to all such factors. The experiments with irradiation show that although some tissues are much more susceptible to the rays than others, there are wide differences in the effects of the rays on different individuals.

In conclusion, I desire to express my thanks to my colleague, Professor B. W. Snow, for the use of the Roentgen ray apparatus belonging to the Department of Physics, and for his aid in conducting the exposures.

EXPLANATION OF PLATES I to V.

On these plates there are represented outlines of the external forms and transverse sections through the body of one control and five experiment larvæ. Descrjptions of the larvæ represented are to be found in the text as follows:

$\begin{array}{ll}\text { Plate I, p. 21 } & \text { Plate IV-A, p. 3I } \\ \text { Plate II, p. 24 } & \text { Plate IV-B, p. } 37 \\ \text { Plate III, p. 27 } & \text { Plate V, P. } 35\end{array}$

${ }^{85}$ Dareste: Recherches sur la production artificielle des monstruosités. Paris isgr.

"Fêré: Comptes Rendus de la Société de Biologie, I893-1905

"Roux: Gesammelte Abhandlungen über Entwicklungsmechanik der Organismen, i895. 
ABNORMAL DEVELOPMENT OF TOAD OVA

PLATE I

Charles Russell Bardien
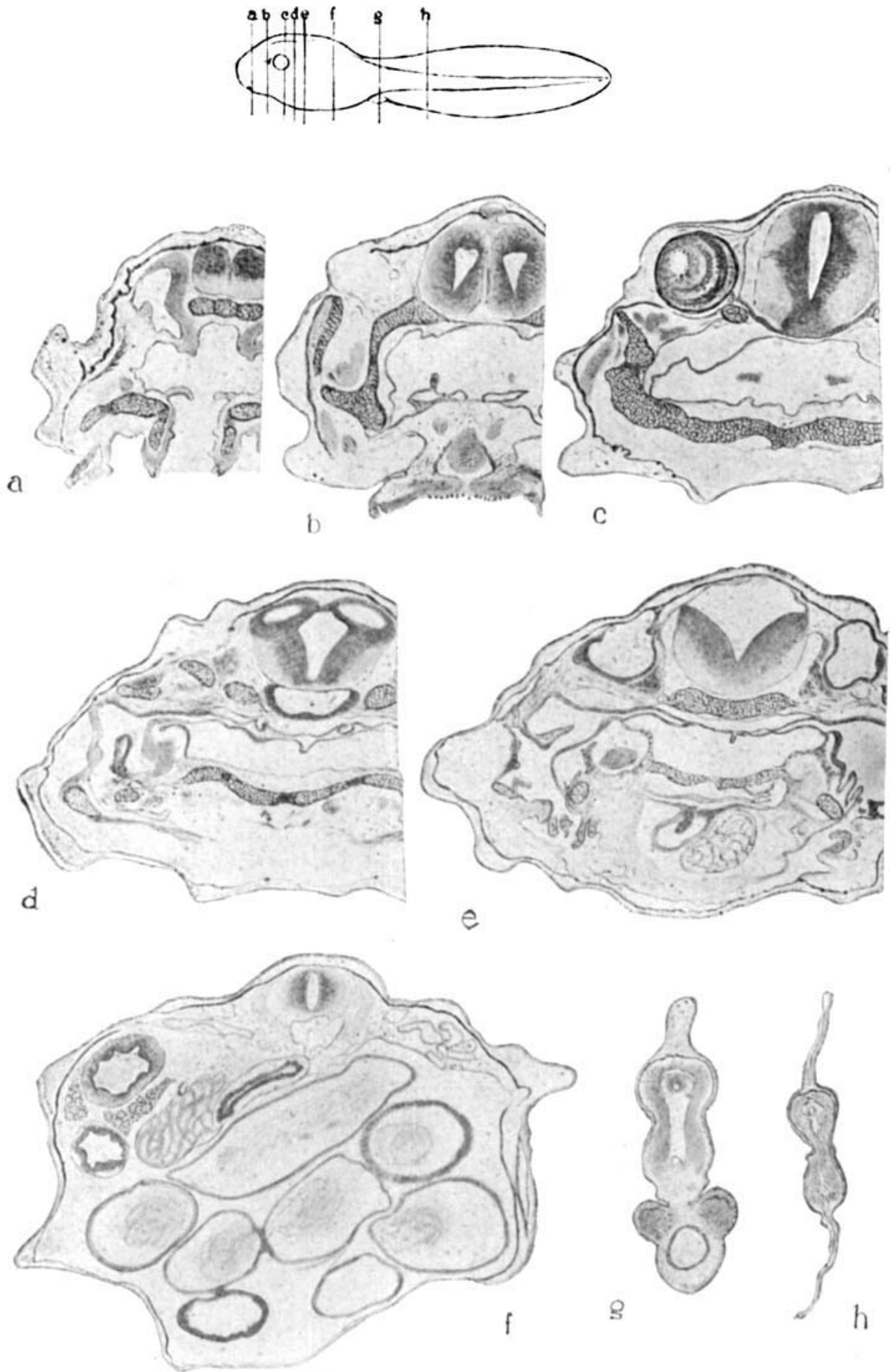

The Journal of Experjmental Zoölogy, vol, iv, No. I 
Charlys Russell Bardeen
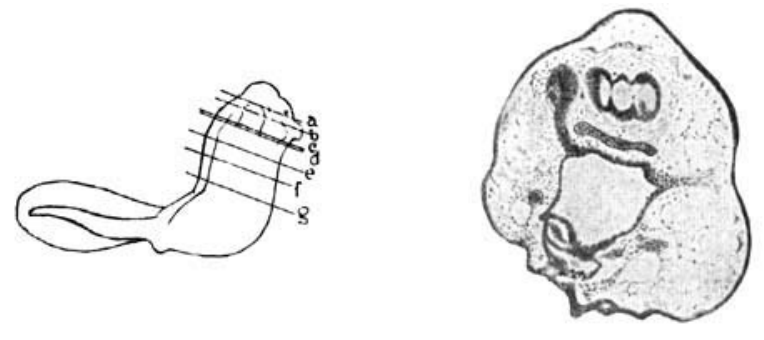

a
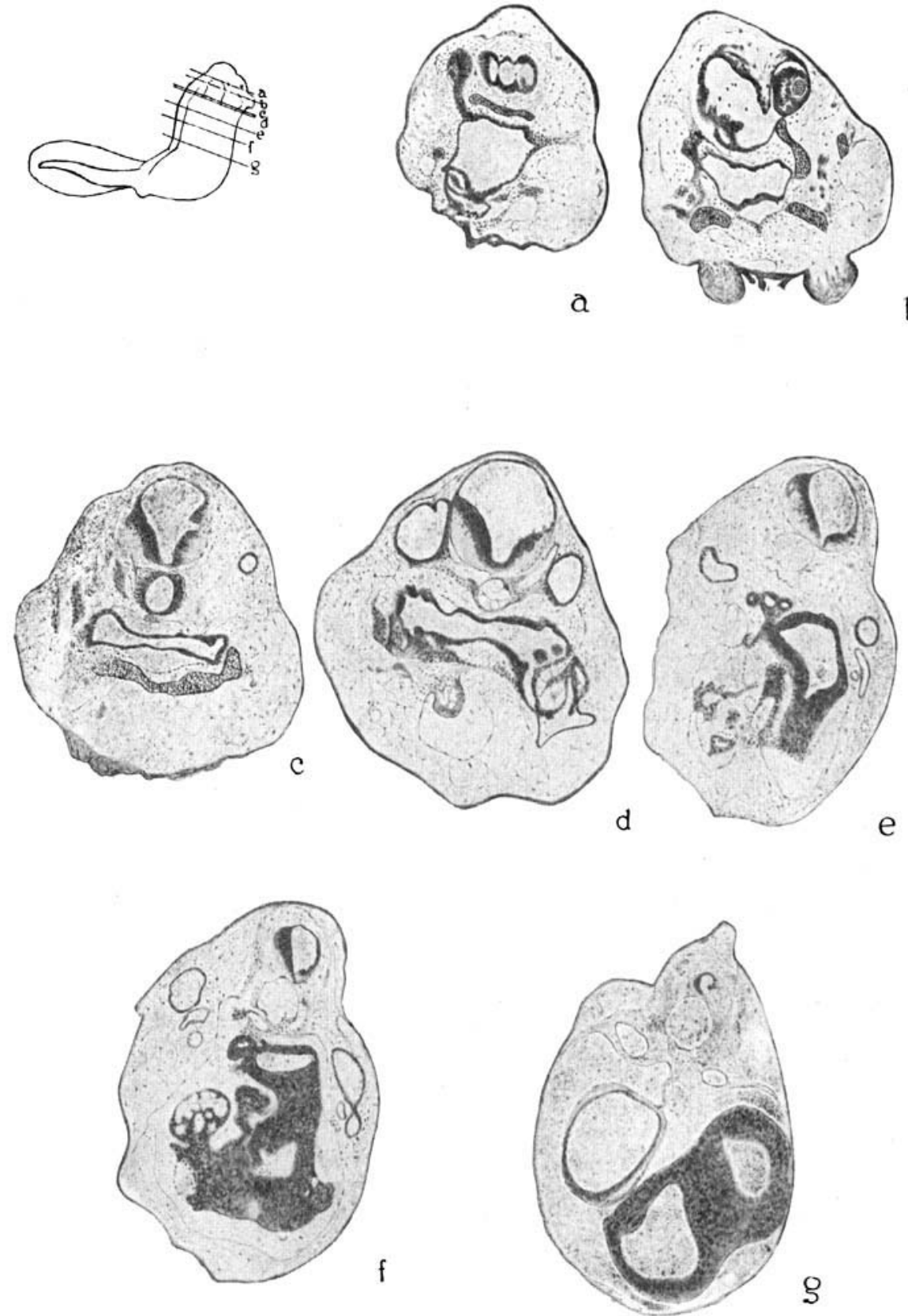

The Journal of Experimental Zoölogy, vol. IV, No. I 
Charles Russell Bardern
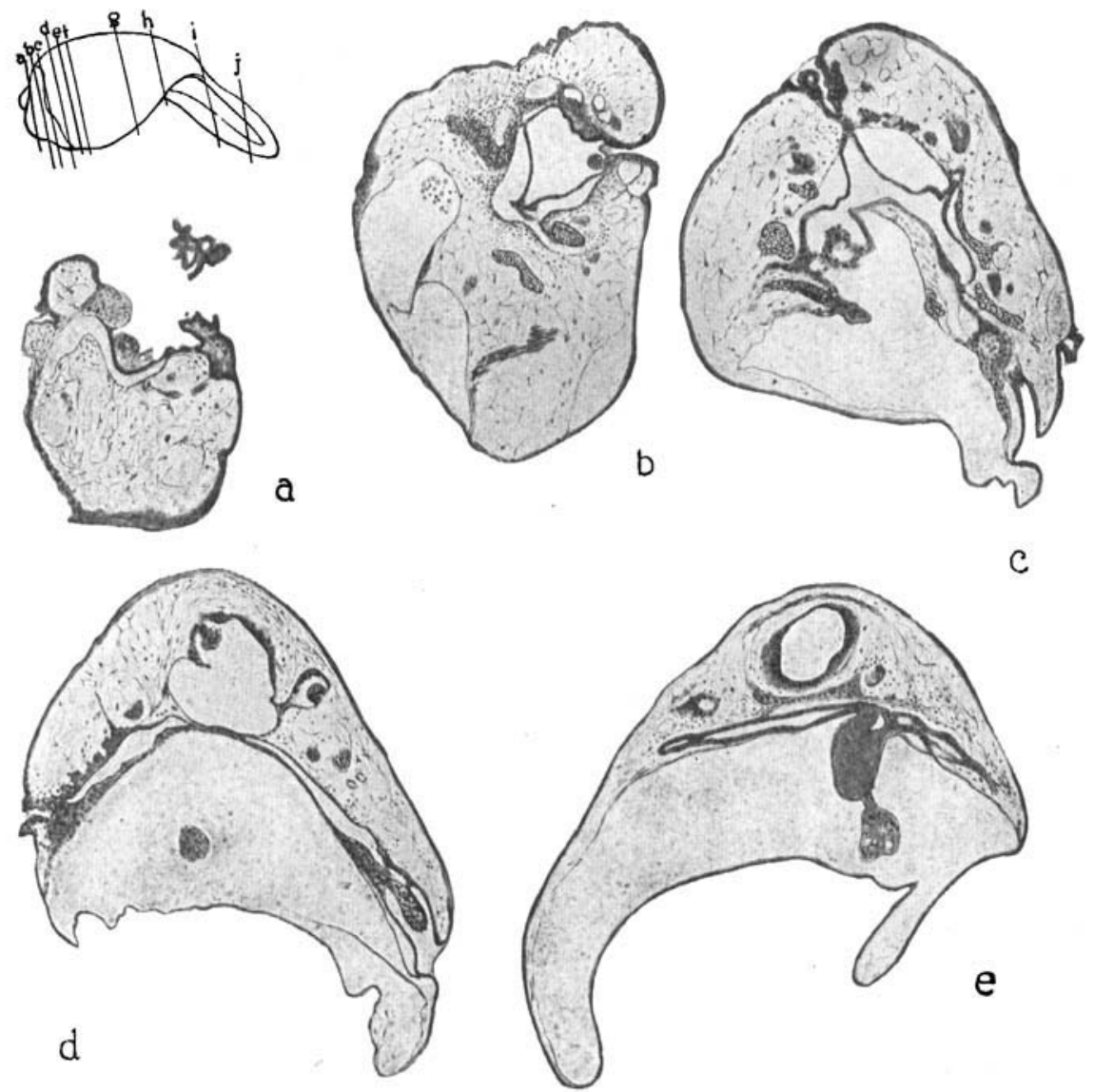

C
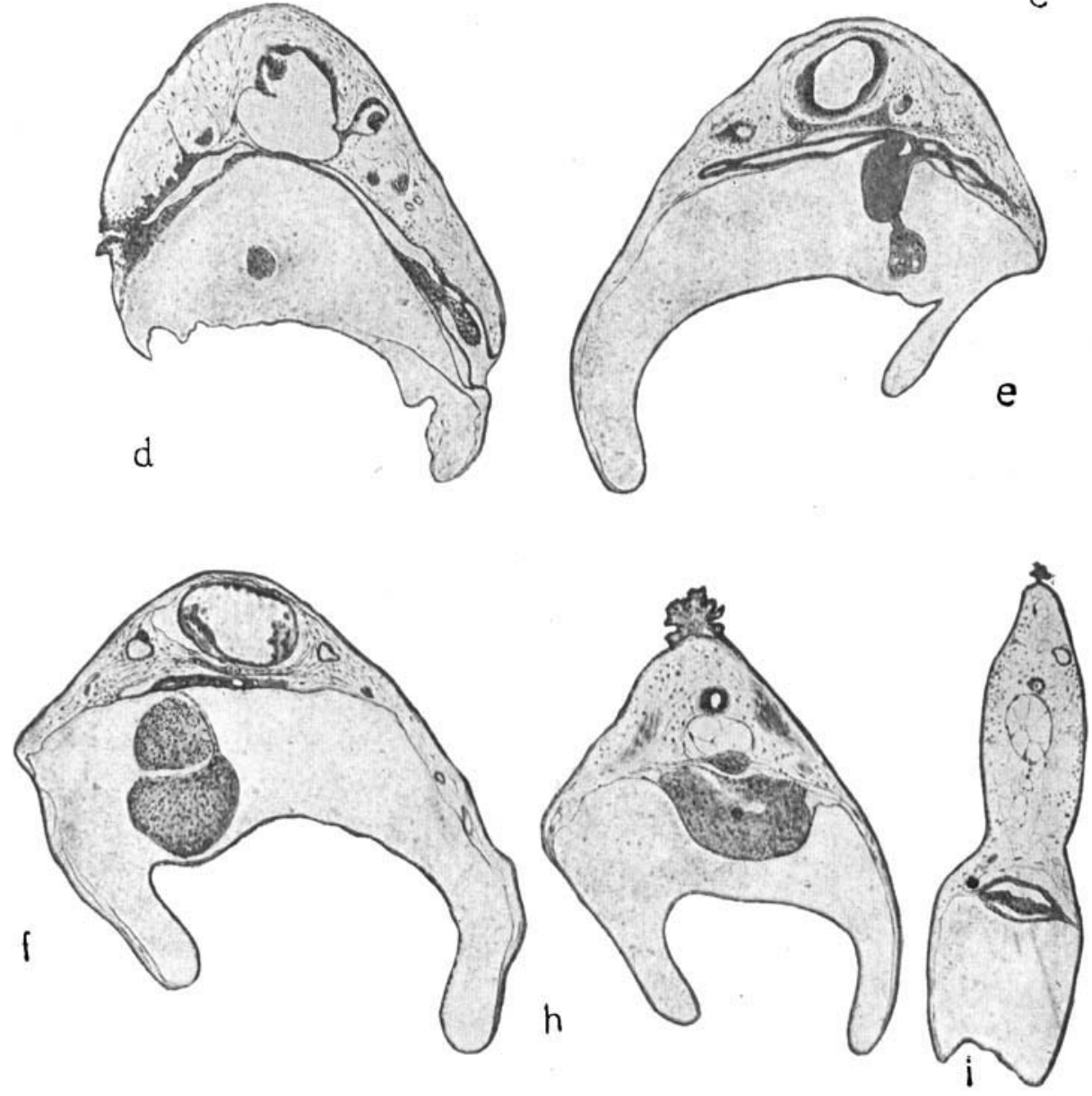

The Journal of Experimental Zoölogy vol, iv, No. 

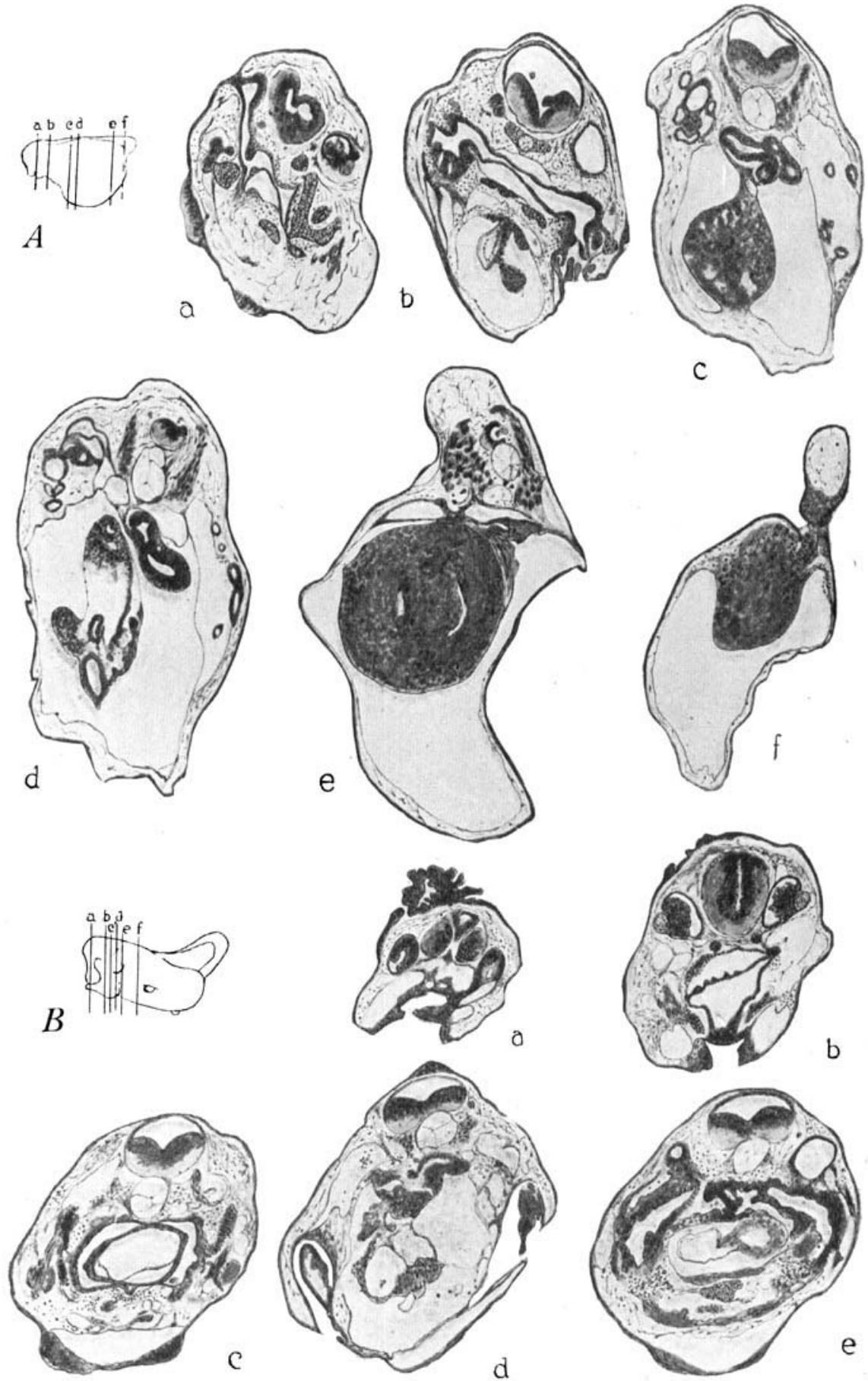

The Journal of Experimental Zoölogt, vol. iv, No. I 

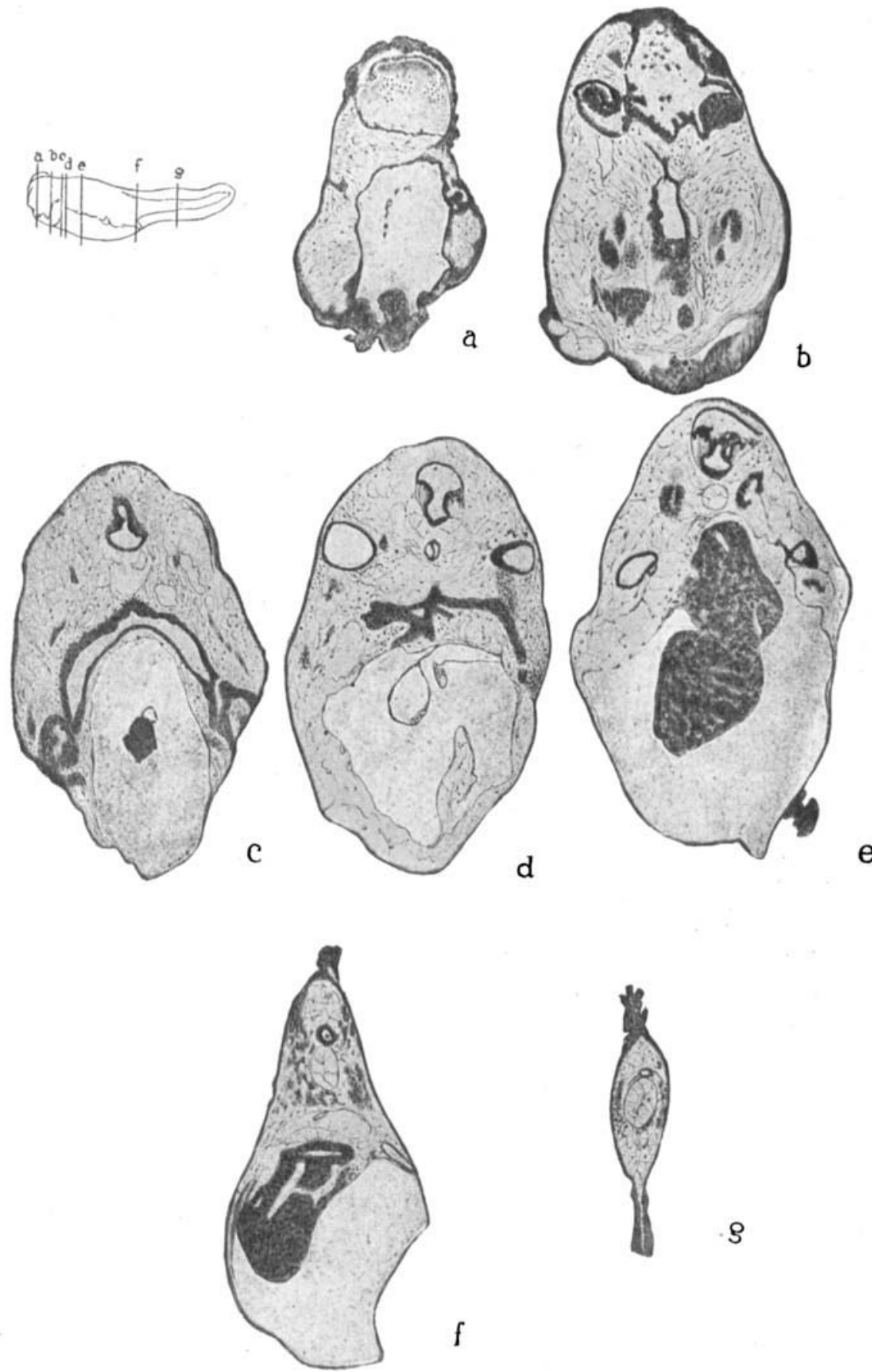

The Journal of Experimental Zoölogy, vol. iv, No. I 